\title{
Pathophysiological Basis for Nutraceutical Supplementation in Heart Failure: A Comprehensive Review
}

\author{
Vincenzo Mollace ${ }^{1, *(\mathbb{D})}$, Giuseppe M. C. Rosano ${ }^{2,3}$, Stefan D. Anker ${ }^{4}$, Andrew J. S. Coats ${ }^{3}$, Petar Seferovic ${ }^{5}$, \\ Rocco Mollace ${ }^{1,6}{ }^{1}$, Annamaria Tavernese ${ }^{1,6}$, Micaela Gliozzi ${ }^{1}$, Vincenzo Musolino ${ }^{1}$, Cristina Carresi ${ }^{1}$, \\ Jessica Maiuolo ${ }^{1}$, Roberta Macrì ${ }^{1}$, Francesca Bosco ${ }^{1}$, Marcello Chiocchi ${ }^{7}$, Francesco Romeo ${ }^{8}$, Marco Metra ${ }^{6}$ and \\ Maurizio Volterrani ${ }^{3}$ (D)
}

check for updates

Citation: Mollace, V.; Rosano, G.M.C.; Anker, S.D.; Coats, A.J.S.; Seferovic, P.; Mollace, R.; Tavernese, A.; Gliozzi, M.; Musolino, V.; Carresi, C.; et al. Pathophysiological Basis for Nutraceutical Supplementation in Heart Failure: A Comprehensive Review. Nutrients 2021, 13, 257. https://doi.org/10.3390/nu13010257

Received: 11 November 2020

Accepted: 13 January 2021

Published: 17 January 2021

Publisher's Note: MDPI stays neutra with regard to jurisdictional claims in published maps and institutional affiliations.

Copyright: (c) 2021 by the authors. Licensee MDPI, Basel, Switzerland. This article is an open access article distributed under the terms and conditions of the Creative Commons Attribution (CC BY) license (https:// creativecommons.org/licenses/by/ $4.0 /)$.
1 Department of Health Sciences, Institute of Research for Food Safety \& Health, University "Magna Graecia" of Catanzaro, 88100 Catanzaro, Italy; rocco.mollace@gmail.com (R.M.); an.tavernese@gmail.com (A.T.); micaela.gliozzi@gmail.com (M.G.); xabaras3@hotmail.com (V.M.); carresi@unicz.it (C.C.); jessicamaiuolo@virgilio.it (J.M.); robertamacri85@gmail.com (R.M.); francesca-bosco88@libero.it (F.B.)

2 Cardiology Clinical Academic Group, St George's Hospitals NHS Trust University of London, London SW17 0QT, UK; giuseppe.rosano@gmail.com

3 Department of Cardiology, IRCCS San Raffaele Pisana, 00166 Rome, Italy; andrewjscoats@gmail.com (A.J.S.C.); maurizio.volterrani@sanraffaele.it (M.V.)

4 Department of Cardiology, Charité-Universitätsmedizin Berlin, 10117 Berlin, Germany; s.anker@cachexia.de

5 Faculty of Medicine, Belgrade University, 11000 Belgrade, Serbia; seferovic.petar@gmail.com

6 Department of Experimental and Applied Medicine, Institute of Cardiology, University of Brescia, 25121 Brescia, Italy; metramarco@libero.it

7 Department of Diagnostic Imaging and Interventional Radiology, Policlinico Tor Vergata, 00199 Rome, Italy; marcello.chiocchi@gmail.com

8 Department of Experimental Medicine, University of Rome "Tor Vergata", 00199 Rome, Italy; romeocerabino@gmail.com

* Correspondence: mollace@libero.it

Abstract: There is evidence demonstrating that heart failure (HF) occurs in 1-2\% of the global population and is often accompanied by comorbidities which contribute to increasing the prevalence of the disease, the rate of hospitalization and the mortality. Although recent advances in both pharmacological and non-pharmacological approaches have led to a significant improvement in clinical outcomes in patients affected by HF, residual unmet needs remain, mostly related to the occurrence of poorly defined strategies in the early stages of myocardial dysfunction. Nutritional support in patients developing HF and nutraceutical supplementation have recently been shown to possibly contribute to protection of the failing myocardium, although their place in the treatment of HF requires further assessment, in order to find better therapeutic solutions. In this context, the Optimal Nutraceutical Supplementation in Heart Failure (ONUS-HF) working group aimed to assess the optimal nutraceutical approach to HF in the early phases of the disease, in order to counteract selected pathways that are imbalanced in the failing myocardium. In particular, we reviewed several of the most relevant pathophysiological and molecular changes occurring during the early stages of myocardial dysfunction. These include mitochondrial and sarcoplasmic reticulum stress, insufficient nitric oxide (NO) release, impaired cardiac stem cell mobilization and an imbalanced regulation of metalloproteinases. Moreover, we reviewed the potential of the nutraceutical supplementation of several natural products, such as coenzyme Q10 (CoQ10), a grape seed extract, Olea Europea L.-related antioxidants, a sodium-glucose cotransporter (SGLT2) inhibitor-rich apple extract and a bergamot polyphenolic fraction, in addition to their support in cardiomyocyte protection, in $\mathrm{HF}$. Such an approach should contribute to optimising the use of nutraceuticals in HF, and the effect needs to be confirmed by means of more targeted clinical trials exploring the efficacy and safety of these compounds.

Keywords: heart failure; dysfunctional cardiomyocytes; patho-physiological mechanisms; oxidative stress; nutraceuticals 


\section{Introduction}

Heart failure (HF) represents a multifactorial disease state with a global prevalence of $1-2 \%$ in the population [1]. Comorbidities frequently associated with HF are hypertension, diabetes, and obesity or hyperlipidaemia. These comorbidities thereby increase the prevalence of the disease, the rate of hospitalisation, and mortality [2,3]. In addition, ageing affects the number of patients experiencing HF; the occurrence of the disease rises to $10 \%$ in people aged $>70$ years $[4,5]$.

According to recent international treatment guidelines, better management of risk factors and increased pharmacological and non-pharmacological treatment significantly reduce the impact of $\mathrm{HF}$ and its consequences. In particular, recent data from a pilot study on HF performed by the European Society of Cardiology (ESC) showed that the all-cause mortality prevalence, at 12 months, was $17 \%$ for hospitalised HF patients and $7 \%$ for stable/ambulatory HF patients, with hospitalisation rates for the same period being $44 \%$ and $32 \%$, respectively [1]. Hence, several relevant outcomes of HF remain unsatisfactory and additional studies are required to address the currently unmet needs in the management of the disease.

Recently, growing evidence has suggested that greater control of the nutritional balance in patients experiencing HF (with special regards to the micronutrient and nutraceutical supply) leads to a significant improvement in the symptoms and consequences of the disease [5-7]. On the other hand, the identification of novel biomolecular mechanisms that lead to the onset of HF, which are only partially counteracted by current treatments, suggests the potential for an additional contribution in the management of HF via optimal micronutrient and nutraceutical supplementation [8-12].

There is evidence that the majority of HF patients exhibit an insufficient support of micronutrients and that such a condition leads to an increased prevalence of the disease [13-16]. Moreover, conditions of dysfunctional myocardium and impaired muscle functionality are accompanied by oxidative stress and micronutrient deficiency [13-17]. Finally, there is also evidence that an insufficient micronutrient supply may trigger $\mathrm{HF}$, as well as impair a pre-existing condition of cardiac dysfunction [13,17].

Additionally, multiple conditions related to micronutrient deficiency can lead to a depletion of the lean body mass (LBM). A pro-inflammatory state, inadequate intake, metabolic changes, increased oxidative stress and increased nutrient loss can all contribute to a loss of LBM. Furthermore, the depletion of LBM can affect vital organs, including the myocardium, thereby negatively influencing its functional capacity [12-16].

Although preliminary evidence suggests that nutraceutical supplementation could be beneficial in treating patients undergoing a decaying heart performance, there is limited evidence supporting its extensive use in patients with HF, as reported in recent studies and meta-analyses $[18,19]$ (Table 1). The major weaknesses in the existing evidence include the small number of studies performed and the inconsistent number of study participants, which is associated with a diminished study quality with a high risk of bias. Considering this, definite conclusions cannot be drawn. Consequently, it is the general opinion that clinicians should presently favour other treatments that have clearly been shown to decrease mortality [18-20] (Table 2). 
Table 1. Protective effects of nutritional components in clinical trials.

\begin{tabular}{|c|c|c|c|c|c|}
\hline $\begin{array}{c}\text { Bioactive } \\
\text { Component }\end{array}$ & Clinical Trials & Study Duration & Dosage Supplement & Properties & References \\
\hline \multirow[b]{2}{*}{ Coenzyme Q10 } & $\begin{array}{l}\text { - Meta-analysis of } 13 \text { randomised } \\
\text { controlled trials } \\
\text { - Includes } 395 \text { participants }(49.8 \text { to } \\
68.0 \text { years) } \\
\text { At baseline: } \\
\text { - Blood CoQ }{ }_{10} \text { concentration } \\
0.61-1.01 \mu \mathrm{g} / \mathrm{mL} \text {. } \\
\text { - EF } 22-46 \% \text {. } \\
\text { - NYHA functional class } 2.3-3.4\end{array}$ & 4-28 weeks & 60-300 mg/day & $\begin{array}{l}\text { - Pooled mean net increase in } \\
\text { blood } \mathrm{COQ}_{10} \text { concentration: } \\
1.4 \mu \mathrm{g} / \mathrm{mL}(95 \% \mathrm{CI}: 1.1, \\
1.7 \mu \mathrm{g} / \mathrm{mL}) \\
\text { - Pooled mean net increase in } \\
\text { EF: } 3.67 \% \\
\text { (95\% CI: } 1.60 \%, 5.74 \%) \\
\text { - Study-specific changes in EF } \\
\text { CoQ } 10 \text { supplementation vs. } \\
\text { placebo: }-3.0 \%(95 \% \mathrm{CI}:-10.7 \% \text {, } \\
4.7 \%) \text { to } 17.8 \% \\
\text { (95\% CI: } 7.2 \%, 28.4 \%) \\
\text { - Pooled mean net change in } \\
\text { NYHA classification: }-0.30 \\
\text { (95\% CI: }-0.66,0.06)\end{array}$ & {$[21]$} \\
\hline & $\begin{array}{l}\text { - A randomised controlled } \\
\text { multicenter trial } \\
\text { Q-SYMBIO } \\
\text { - Includes } 420 \text { patients with } \\
\text { moderate to severe HF } \\
\text { At baseline: } \\
\text { - Chronic HF in NYHA functional } \\
\text { class III or IV } \\
\text { - Typical symptoms and signs } \\
\text { of HF } \\
\text { - No specific cut-point related } \\
\text { to EF }\end{array}$ & $\begin{array}{l}\text { Primary short-term } \\
\text { endpoints } \\
\text { (16 weeks): } \\
\text { - NYHA functional class } \\
\text { and functional status } \\
\text { - VAS for symptoms } \\
\text { - 6MWT } \\
\text { - echocardiography } \\
\text { - Serum samples for } \\
\text { CoQ10 and } \\
\text { NT-proBNP. } \\
\text { Primary long-term } \\
\text { endpoint } \\
\text { (106 weeks): } \\
\text { - Morbidity and } \\
\text { mortality } \\
\text { - VAS for symptoms } \\
\text { - MACE }\end{array}$ & $100 \mathrm{mg} 3$ times/day & $\begin{array}{l}\text { After 16weeks: } \\
\text { - The level of serum } \\
\text { CoQ10-treated group increased to } \\
\text { about } 3 \text { times the baseline value } \\
\text { - NT-proBNP reduction } \\
\text { (mean value of } 384 \mathrm{pg} / \mathrm{mL}(20 \%) \\
\text { vs. } 199 \mathrm{pg} / \mathrm{mL}(12 \%) \\
\text { After } 106 \text { weeks: } \\
\text { - Fewer MACE ( } N=30,15 \% \text { vs. } \\
N=57,26 \% \text { ) } \\
\text { - Improved NYHA functional } \\
\text { classification }(N=86,58 \% \text { vs. } \\
N=68,45 \% \text { ) } \\
\text { - At least } 1 \text { grade of improvement } \\
\text { in NYHA functional class } \\
\text { - Reduced serum NT-proBNP } \\
\text { (mean value of } 1137 \mathrm{pg} / \mathrm{mL} ; \\
60 \% \text { vs. mean value } \\
881 \text { pg/mL; } 52 \%) \\
\text { - Lower total number of } \\
\text { cardiovascular deaths } \\
\text { ( } N=18,9 \% \text { vs. } N=34,16 \%), \\
\text { corresponding to a } 43 \% \\
\text { relative reduction. } \\
\text { - Lower number of hospital stays } \\
\text { for HF ( } N=17,8 \% \text { vs. } \\
N=31,14 \% \text { ) } \\
\text { - Lower number of adverse events } \\
\text { (mean value } 26(13 \% \text { ) vs. } 41(19 \%)\end{array}$ & [22] \\
\hline $\mathrm{BPF}$ & $\begin{array}{l}\text { - A randomised, double-blind, } \\
\text { placebo-controlled study } \\
\text { - Includes } 237 \text { patients: } \\
\text { group A (104 patients) with } \\
\text { isolated HC } \\
\text { (LDL-C levels } \geq 130 \mathrm{mg} / \mathrm{dL}) \\
\text { group B ( } 42 \text { patients) with } \\
\text { HC/HT } \\
\text { group C ( } 59 \text { patients) with mixed } \\
\text { HC/HT } / \mathrm{HG} \\
\text { over } 110 \mathrm{mg} / \mathrm{dL} \\
\text { group D ( } 32 \text { patients) who } \\
\text { stopped simvastatin therapy }\end{array}$ & 30 consecutive days & $\begin{array}{l}500,1000 \text { or } \\
1500 \mathrm{mg} / \text { day }\end{array}$ & $\begin{array}{l}\text { - In group A, B and C } \\
\text { reduction in: } \\
\text { - tChol (mean value from } \\
278 \mathrm{mg} / \mathrm{mL} \text { to } 199 \mathrm{mg} / \mathrm{mL}) \\
\text { - LDL-C (mean value from } \\
188 \mathrm{mg} / \mathrm{mL} \text { to } 126 \mathrm{mg} / \mathrm{mL}) \\
\text { - TG (mean value from } \\
267 \mathrm{mg} / \mathrm{mL} \text { to } 158 \mathrm{mg} / \mathrm{mL} \text { ) } \\
\text { - Increase in HDL-C was observed } \\
\text { with the best response in } \\
\text { the } 10 \% \text { subjects }(-64.6 \% \text { ) } \\
\text { - Reduction in blood } \\
\text { glucose levels } \\
\text { (mean value of }-18.9 \% \text { under } 500 \\
\text { mg BPF treatment and } \\
\text {-22.4\% in } 1000 \mathrm{mg} \\
\text { BPF treatment) } \\
\text { - Group D, } 30 / 32 \text { patients } \\
\text { showed a reduction in tChol } \\
\text { (mean - } 25 \% \text { and LDL-C - } 27.6 \% \text { ) } \\
\text { - Increasing flow- } \\
\text { mediated vasodilation }\end{array}$ & [23] \\
\hline
\end{tabular}


Table 1. Cont.

\begin{tabular}{|c|c|c|c|c|c|}
\hline $\begin{array}{l}\text { Bioactive } \\
\text { Component }\end{array}$ & Clinical Trials & Study Duration & Dosage Supplement & Properties & References \\
\hline & $\begin{array}{l}\text { - A randomised double-blind, } \\
\text { placebo-controlled study } \\
\text { - Includes } 60 \text { patients suffering } \\
\text { from T2DM with: } \\
\text { Serum glucose }>110 \mathrm{mg} / \mathrm{dL}) \text { ) } \\
\text { Mixed hyperlipemia } \\
(\mathrm{LDL}-\mathrm{C}>120 \mathrm{mg} / \mathrm{dL} \text { and } \\
\text { TG }>175 \mathrm{mg} / \mathrm{dL} \text { ) }\end{array}$ & 30 consecutive days & $\begin{array}{l}650 \mathrm{mg} \mathrm{BPF} \\
\text { twice/day }\end{array}$ & $\begin{array}{l}\text { - Fasting plasma glucose } \\
\text { (from } 120 \pm 1.6 \mathrm{mg} / \mathrm{mL} \text { to } \\
98 \pm 1.3 \mathrm{mg} / \mathrm{mL}) \\
\text { - tChol }(262 \pm 14 \mathrm{mg} / \mathrm{dL} \text { to } \\
196 \pm 12 \mathrm{mg} / \mathrm{dL}) \\
\text { - LDL-C }(175 \pm 5.8 \mathrm{mg} / \mathrm{mL} \text { to } \\
116 \pm 3.2 \mathrm{mg} / \mathrm{mL}) \\
\text { - HDL-C }(44 \pm 4.1 \mathrm{mg} / \mathrm{mL} \text { to } \\
48+3.8 \mathrm{mg} / \mathrm{mL}) \\
\text { - Triglycerides }(252 \pm 9 \mathrm{mg} / \mathrm{mL} \\
\text { to } 170+7 \mathrm{mg} / \mathrm{mL}) \\
\text { - Relevant changes in mean } \\
\text { particle diameters for } \\
\text { VLDL, LDL, and HDL } \\
\text { - Decrease the mean } \\
\text { concentration of IDL particles to } \\
\text { Increase large LDL and to } \\
\text { decrease small LDL. } \\
\text { - Increase in total HDL particles }\end{array}$ & [24] \\
\hline & $\begin{array}{l}\text { - A prospective, open-label, } \\
\text { parallel group, placebo- } \\
\text { controlled study } \\
\text { - Includes } 77 \text { patients mixed } \\
\text { hypercholesterolemia } \\
\text { (LDL-C }=160 \mathrm{mg} / \mathrm{dL} \text {, } \\
\text { TG }=225 \mathrm{mg} / \mathrm{dL} \text { ) }\end{array}$ & 30 consecutive days & $\begin{array}{l}\text { - Rosuvastatin (10 } \\
\text { and } 20 \mathrm{mg} / \text { day) } \\
\text { - BPF (1000 mg/day) } \\
\text { - BPF+rosuvastatin } \\
\text { (10 mg/day) }\end{array}$ & 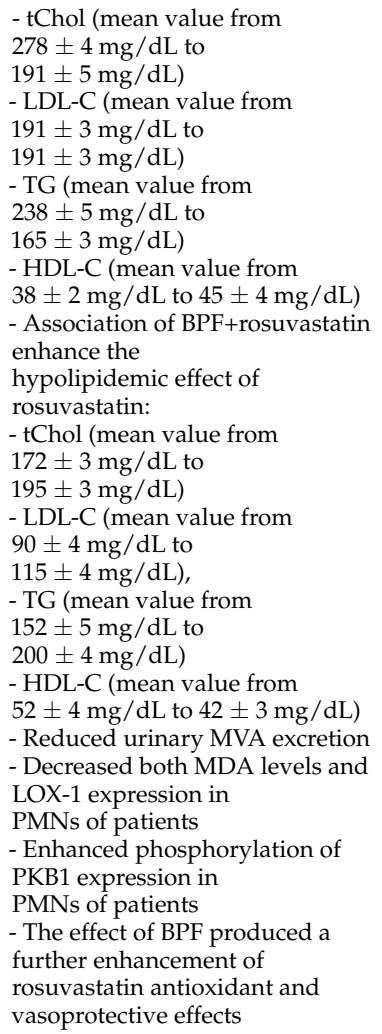 & [25] \\
\hline \multirow[b]{2}{*}{$\begin{array}{l}\text { Oleuropein, } \\
\text { hydroxytyrosol }\end{array}$} & $\begin{array}{l}\text { - An open, controlled, } \\
\text { parallel-group, co-twin study } \\
\text { - Including } 40 \text { borderline } \\
\text { hypertensive monozygotic } \\
\text { patients ( } 18 \text { and } 60 \text { years) with: } \\
\text { an untreated SBP }>120 \mathrm{mmHg} \text { or } \\
\text { DBP }>80 \mathrm{mmHg} \text { at rest }\end{array}$ & 8 weeks & $\begin{array}{l}500 \mathrm{mg} \text { and } \\
1000 \mathrm{mg} / \text { day }\end{array}$ & $\begin{array}{l}\text { - } 1000 \text { mg significantly reduces: } \\
\text { SBP (mean value } 126 \pm 9 \text { vs. } \\
137 \pm 10) \\
\text { DBP }(76 \pm 6 \text { vs. } 80 \pm 10) \\
\text { - Reduction in LDL-C }\end{array}$ & {$[26]$} \\
\hline & $\begin{array}{l}\text { - A double-blind, randomised, } \\
\text { parallel and active- } \\
\text { controlled clinical study } \\
\text { - Includes } 232 \text { patients ( } 25 \text { and } \\
60 \text { years) } \\
\text { in stage- } 1 \text { hypertension } \\
\text { with SBP of } 140-159 \mathrm{mmHg} \text {, } \\
\text { DBP < } 90 \mathrm{mmHg} \\
\text { or in between } 90 \text { and } 99 \mathrm{mmHg}\end{array}$ & $\begin{array}{l}\text { - 4-weeks single-blind } \\
\text { placebo (is diet-alone) } \\
\text { - Run-in period and } \\
\text { followed by 8-weeks } \\
\text { double-blind } \\
\text { treatment period }\end{array}$ & $\begin{array}{l}500 \mathrm{mg} \text { twice/day vs. } \\
\text { captopril treatment } \\
(12.5 \mathrm{mg} \text { twice/day) }\end{array}$ & $\begin{array}{l}\text { - significant reduction in: } \\
\text { SBP }(-11.5 \pm 8.6 \mathrm{mmHg} \text { vs. } \\
-13.7 \pm 7.6 \mathrm{mmHg} \text { in captopril }) \\
\mathrm{DBP}(-4.8 \pm 5.5 \mathrm{mmHg} \text { vs. } \\
-6.4 \pm 5.2 \mathrm{mmHg} \text { captopril }) \\
\text { - } \mathrm{LDL}-\mathrm{C}(-3.89 \pm 19.40 \mathrm{mg} / \mathrm{dL} \\
\text { vs. } 2.14 \pm 14.20 \mathrm{mg} / \mathrm{dL} \\
\text { in captopril }) \\
\text { - TG }(-11.90 \pm 46.17 \mathrm{mg} / \mathrm{dL} \text { vs. } \\
-1.26 \pm 43.31 \mathrm{mg} / \mathrm{dL} \\
\text { in captopril })\end{array}$ & [27] \\
\hline
\end{tabular}


Table 1. Cont.

\begin{tabular}{|c|c|c|c|c|c|}
\hline $\begin{array}{l}\text { Bioactive } \\
\text { Component }\end{array}$ & Clinical Trials & Study Duration & Dosage Supplement & Properties & References \\
\hline \multirow[t]{2}{*}{ SGLT2-inhibitors } & $\begin{array}{l}\text { - EMPA-REGOUTCOMEtrial, a } \\
\text { cardiovascular } \\
\text { outcome trial } \\
\text { - Includes } 7020 \text { patients ( } \geq 18 \\
\text { years) with T2DM at high risk of } \\
\mathrm{CV} \text { disease with: } \\
\text { - BMI } \leq 45 \mathrm{~kg} / \mathrm{m}^{2} \text {; } \\
\text { - No glucose-lowering therapy in } \\
\text { previous } 12 \text { weeks } \\
\text {-HbA1c } 7.0-9.0 \% \text {, or stable } \\
\text { glucose-lowering } \\
\text { therapy and } \mathrm{HbA} 1 \mathrm{c} 7.0-10.0 \% \\
\text { - Glomerular filtration rate }(\mathrm{eGFR}) \\
\text { of at least } 30 \mathrm{~mL} / \mathrm{min} \times 1.73 \mathrm{~m}^{2} \\
\text { of body-surface area }\end{array}$ & $\begin{array}{l}3 \text { years } \\
\text { Primary long-term } \\
\text { endpoint: } \\
\text { 3P-MACE }\end{array}$ & $10 \mathrm{mg}$ or $25 \mathrm{mg}$ & $\begin{array}{l}\text { Primary outcome: } \\
\text { - All-cause mortality: HR } 0.68 \\
\text { (95\% CI 0.57, } 0.82 ; p<0.001) \\
\text { - Incident or worsening } \\
\text { nephropathy: HR } 0.61 \text { ( } 95 \% \text { CI } \\
0.53,0.70 ; p<0.001) \\
\text { - Lower rates of death from } \\
\text { cardiovascular causes }(3.7 \% \text {, vs. } \\
5.9 \% \text { in te placebo; } 38 \% \text { relative } \\
\text { risk reduction; HR } 0.62 \\
\text { (95\% CI 0.49, } 0.77 ; p<0.001) \\
\text { - Hospitalization for heart failure } \\
\text { (2.7\% and } 4.1 \% \text {, } \\
\text { respectively; } 35 \% \text { relative risk } \\
\text { reduction; HR 0.65 (95\% } \\
\text { CI 0.50, 0.85; } p=0.002) \\
\text { - Death from any cause }(5.7 \% \text { and } \\
8.3 \% \text {, respectively; } 32 \% \text { relative } \\
\text { risk reduction) }\end{array}$ & {$[28]$} \\
\hline & $\begin{array}{l}\text { - Declare-TIMI } 58 \text { trial } \\
\text { - includes } 17,160 \text { patients } \\
\text { (40 years) with T2DM and risk of } \\
\text { atherosclerotic CV disease T2DM; } \\
\text { HbA1c } \geq 6.5 \%\end{array}$ & $\begin{array}{l}\text { 4, } 5 \text { years } \\
\text { Primary long-term } \\
\text { end-point: } \\
\text { - Non-inferiority for } \\
\text { 3P-MACE } \\
\text { - Composite kidney } \\
\text { outcome }\end{array}$ & $10 \mathrm{mg}$ & $\begin{array}{l}\text { Co-primary efficacy } \\
\text { outcomes-3P-MACE: } \\
\text { - lower rate } \\
\text { of cardiovascular death or } \\
\text { hospitalization for heart failure } \\
(4.9 \% \text { vs. } 5.8 \% \text {; HR, } 0.83 ; 95 \% \text { CI, } \\
0.73 \text { to } 0.95 ; p=0.005) \\
\text { - Lower rate of hospitalization for } \\
\text { heart failure (HR, } 0.73 ; 95 \% \text { CI, } \\
0.61 \text { to } 0.88 \text { ) } \\
\text { kidney composite outcome: } \\
\text { - A renal event occurred in } 4.3 \% \\
\text { vs. } 5.6 \% \text { in placebo (HR, } 0.76 \text {; } \\
95 \% \text { CI, } 0.67 \text { to } 0.87 \text { ) } \\
\text { - Death from any cause occurred } \\
\text { in } 6.2 \% \text { and } 6.6 \% \text {, respectively } \\
\text { (HR, } 0.93 ; 95 \% \mathrm{CI}, 0.82 \text { to } 1.04 \text { ) }\end{array}$ & [29] \\
\hline
\end{tabular}

BMI: body mass index; BPF: bergamot polyphenolic fraction; CI: Confidence Interval; EF: ejection fraction; DBP: diastolic blood pressure; HC/HT: hypercholesterolemia and hypertriglyceridemia; HC/HT/HG: hyperlipidemia and glycemia; HDL-C: high density lipoprotein cholesterol; HF: heart failure; HR: hazard ratio; HC: hypercholesterolemia; LDL-C: low density lipoprotein cholesterol; LOX-1: Lectinlike oxidised low-density lipoprotein (LDL) receptor-1; MACE: major adverse cardiovascular events; MDA: malondialdehyde; MVA: mevalonate; NYHA: New York Heart Association; NT-proBNP: N-terminal pro-B-type natriuretic peptide; PMNs: peripheral blood mononuclear cells; PKB: protein kinase B; SBP: systolic blood pressure; tChol: total cholesterol; TG: triglycerides; T2DM: type 2 diabetes mellitus; VAS: visual analogue scale; 6MWT: 6-min walk test; HbA1c: glycated hemoglobin.

Table 2. The main properties of different natural compounds.

\begin{tabular}{|c|c|c|c|c|c|}
\hline Plant & $\begin{array}{c}\text { Bioactive } \\
\text { Component }\end{array}$ & Properties & In Vitro/In Vivo Models & Clinical Trials & References \\
\hline $\begin{array}{l}\text { Brassicaceae family } \\
\text { Gramineae family }\end{array}$ & Coenzyme Q10 & $\begin{array}{l}\text { Antioxidant and } \\
\text { anti-inflammatory activity } \\
\text { Key component of METC and in } \\
\text { ATP production } \\
\text { Bioenergetic effect } \\
\uparrow \text { p-AMPK } \uparrow \text { Akt/eNOS activity } \\
\uparrow \text { HO- } 1 \text { expression } \\
\uparrow \text { hemodynamic parameters } \\
\uparrow \text { LV function } \\
\downarrow 3-N T \downarrow \text { MDA } \\
\downarrow \text { Nox2 gene expression } \\
\uparrow \text { Vasodilation } \downarrow \text { Aldosterone levels } \\
\uparrow \text { Fatty acid oxidation } \uparrow \text { VLDL } \\
\downarrow \text { LDLc/HDLc } \downarrow \text { TC/HDLc } \\
\downarrow \text { Fibrinogen } \\
\downarrow \text { SBP } \downarrow \text { DBP }\end{array}$ & $\begin{array}{l}\text { - EPCs } \\
\text { - Isoproterenol- induced HF } \\
\text { in rats } \\
\text { - Diabetic cardiomyopathy } \\
\text { in mice }\end{array}$ & $\begin{array}{l}\text {-HFrEF } \\
\text { - Hypertension } \\
\text {-T2DM } \\
\text { - MetS } \\
\text { - Hyperlipideima } \\
\text { - MI }\end{array}$ & [18-22,30-38] \\
\hline
\end{tabular}


Table 2. Cont.

\begin{tabular}{|c|c|c|c|c|c|}
\hline Plant & $\begin{array}{l}\text { Bioactive } \\
\text { Component }\end{array}$ & Properties & In Vitro/In Vivo Models & Clinical Trials & References \\
\hline $\begin{array}{l}\text { Citrus Bergamia } \\
\text { Risso et Poiteau }\end{array}$ & BPF & $\begin{array}{l}\downarrow \text { Serum glucose, TG, TC, LDL-C, } \\
\text { VLDL-C } \\
\uparrow \text { HDL-C } \uparrow \text { fecal sterol excretion } \\
\text { Re-arrangement of } \\
\text { lipoprotein particles } \\
\uparrow \text { Lipid transfer protein system } \\
\downarrow \text { pCEH } \\
\uparrow \text { SOD, catalase } \\
\downarrow \text { SMC proliferation, LOX-1, p-PKB } \\
\downarrow \text { ROS, TBARS, MDA, Nitrotyrosine } \\
\uparrow \text { LV function } \downarrow \text { pathologic } \\
\text { cardiac remodelling } \\
\downarrow \text { detrimental autophagy } \\
\downarrow \text { apoptosis } \\
\downarrow \text { OOHdG } \uparrow \text { newly formed myocytes }\end{array}$ & $\begin{array}{l}\text { - eCSCs } \\
\text { - Rat neointimal hyperplasia } \\
\text { - Hypercholesterolemic diet } \\
\text { fed rats } \\
\text { - Doxo-induced cardiotoxicity } \\
\text { in rats }\end{array}$ & $\begin{array}{l}\text { - Hyperlipemia } \\
\text { - MetS } \\
\text { - T2DM }\end{array}$ & {$[23-25,39-47]$} \\
\hline $\begin{array}{l}\text { Oleaceae family } \\
\text { (Olea europaea Linn.) }\end{array}$ & $\begin{array}{l}\text { Oleuropein, } \\
\text { hydroxytyrosol }\end{array}$ & $\begin{array}{l}\downarrow \text { CK-MB, GSSG, TBARS, LDH } \\
\downarrow \text { MDA, 3-NT, ET- } 1 \text {, IL- } \beta, \\
\text { IL-6, TNF } \alpha \\
\uparrow \text { eNOS } \downarrow \text { PCs, iNOS } \\
\uparrow \text { p-Akt, p-AMPK } \uparrow \text { Prdx-1 and } \\
\text { Prdx-2 } \downarrow \text { TC, TG } \\
\uparrow \text { SOD and GSH activity } \\
\uparrow \text { integrity of complex III of } \\
\text { the METC } \\
\downarrow \text { infarct size } \downarrow \text { myocyte apoptosis } \uparrow \\
\text { LV fuction } \\
\uparrow \text { pGS3K- } \beta / \text { GS3K- } \beta \\
\uparrow \text { Sirt- } 1 \text {, pFOXO3a } \\
\downarrow \text { myocardial fibrosis } \\
\downarrow \text { pMEK, pERK1/2, p53, p-IкB } \alpha \\
\uparrow \text { pSTAT-3 } \\
\downarrow \text { CYP2E1, OH-1, NF- } \mathrm{kB}, \text { COX-2 } \\
\downarrow \text { GRP78, CHOP }\end{array}$ & $\begin{array}{l}\text { - VPCs } \\
\text { - CoCl } \mathrm{C}_{2} \text {-induced hypoxia in } \\
\mathrm{H} 9 \mathrm{C} 2 \text { cells } \\
\text { - ISO-induced MI in rats } \\
\text { - Myocardial I/R in rats } \\
\text { - Doxo-treated rats } \\
\text { - Myocardial I/R in } \\
\text { hypercholesterolemic rabbits } \\
\text { - Myocardial infarction in rats } \\
\text { - T2DM and renal hypertension } \\
\text { in rats } \\
\text { - Cisplatin-induced kidney } \\
\text { injury in mice }\end{array}$ & & [48-63] \\
\hline $\begin{array}{l}\text { Malus } \\
\text { Malus sieversii }\end{array}$ & Phlorizin & $\begin{array}{l}\uparrow \text { endothelium-indipendent } \\
\text { relaxation } \\
\downarrow \text { human ox-LDL } \\
\downarrow \text { postprandial blood glucose } \\
\text { rise, HbA1c } \\
\uparrow \text { urinary glucose excretion } \\
\downarrow \text { urinary albumin excretion } \\
\downarrow \text { glycohemoglobin, insulin, TG } \\
\uparrow \text { muscle GLUT4 } \downarrow \text { renal GLUT2 } \\
\downarrow \text { kidney epithelial vacuolization } \\
\downarrow \text { hepatic glucose production } \\
\uparrow \text { ketone bodies amount }\end{array}$ & $\begin{array}{l}\text { - Isolated rabbit } \\
\text { coronary artery } \\
\text { - High-glucose diet in Std } \\
\text { ddY mice } \\
\text { - Neonatally STZ-induced } \\
\text { diabetic rats } \\
\text { - STZ-induced diabetic rats }\end{array}$ & & [64-73] \\
\hline Vitis vinifera & Proanthocyanidins & $\begin{array}{l}\text { free radical scavenging activity } \\
\downarrow \text { TBARS levels } \\
\downarrow \text { DNA fragmentation } \\
\downarrow \text { p53 } \uparrow \text { Bcl-2, Bcl-XL } \\
\downarrow \text { liver toxicity and } \\
\text { DNA fragmentation } \\
\downarrow \text { hepatocyte apoptosis and necrosis } \\
\downarrow \text { JNK-1, c-Jun } \\
\downarrow \text { cardiomyocyte apoptosis } \\
\uparrow \text { post-ischemic cardiac function } \\
\uparrow \text { mitochondrial IDH, SDH, } \\
\text { MDH, } \alpha-K G D H \\
\uparrow \text { respiratory chain NADH } \\
\text { dehydrogenase and CCO }\end{array}$ & $\begin{array}{l}\text { - TPA-induced ROS/RNS } \\
\text { in mice } \\
\text { - Human oral keratinocytes } \\
\text { - AAP-induced liver injury } \\
\text { in mice } \\
\text { - Myocardial I/R in rats }\end{array}$ & & [74-82] \\
\hline
\end{tabular}


Table 2. Cont.

\begin{tabular}{|c|c|c|c|c|c|}
\hline Plant & $\begin{array}{l}\text { Bioactive } \\
\text { Component }\end{array}$ & Properties & In Vitro/In Vivo Models & Clinical Trials & References \\
\hline $\begin{array}{l}\text { Zygophyllaceae family } \\
\text { (Tribulus terrestris L.) }\end{array}$ & $\begin{array}{l}\text { ferulic acid, } \\
\text { diosgenin, } \\
\text { saponins }\end{array}$ & $\begin{array}{l}\uparrow \text { Total antioxidant activity } \\
\uparrow \text { SOD, GPx, CAT activity } \downarrow \text { MDA } \\
\downarrow \text { LDH, CK-MB, SGOT, } \\
\text { SGPT, Calcium } \\
\uparrow \text { cell viability } \\
\uparrow \text { Integrity of mitochondrial PTP } \\
\uparrow \text { Activity of mitochondrial } \\
\text { respiratory complexes } \\
\uparrow \text { oxygen consumption rate } \uparrow \text { ATP } \\
\text { level } \downarrow \text { HIF- } 1 \alpha \\
\uparrow \text { Mitochondrial OPA1, Mfn1, Mfn2 } \\
\downarrow \text { Drp1 and Fis1 } \\
\downarrow \text { Bax, Bad } \uparrow \text { Bcl-2, p-Akt } \\
\downarrow \text { p-P38, p-JNK } \\
\downarrow \text { Heart rate } \downarrow \text { cardiac fibrosis } \\
\downarrow \text { IL-6, TNF } \alpha, \text { IL- } 1 \beta, \text { MCP- } 1 \uparrow \text { IL-10 } \\
\downarrow \text { Nuclear traslocation of NF- KB } \\
\uparrow \text { coronary artery dilation } \uparrow \text { ECG }\end{array}$ & $\begin{array}{l}\text { - Myocardial ischemia in H9C2 } \\
\text { - ISO-induced ischemia in rats }\end{array}$ & - Angina pectoris & [83] \\
\hline Vitis vinifera & Resveratrol & $\begin{array}{l}\uparrow \text { oxygen consumption rate } \uparrow \text { SIRT1 } \\
\text { and p-AMPK } \\
\downarrow \text { PCG } \alpha \text { acetylation } \uparrow \text { PCG1 } \alpha \\
\text { activity } \uparrow \text { insulin sensitivity } \\
\uparrow \text { endothelial function } \uparrow \text { SBP } \uparrow \\
\text { adiponectin, IL-10 } \\
\downarrow \text { PAI- } 1, \text { hsCRP, TNF } \alpha, \text { IL-6 } \\
\downarrow \text { HbA1c, TC, TG } \downarrow \text { number of } \\
\text { angina episodes } \\
\uparrow \text { LV diastolic function } \downarrow \text { ANP } \\
\uparrow \text { LC3II/LC3I } \downarrow \text { p-mTOR, p-p70S6K } \\
\uparrow \text { myocardial ATP content } \downarrow \\
\text { cleaved-caspase-3 }\end{array}$ & $\begin{array}{l}\text { - C2C12 mouse myoblast cells } \\
\text { - MEFs (mouse embrionic } \\
\text { fibroblasts) } \\
\text { - H9C2 cells } \\
\text { - Isolated gastrocnemius } \\
\text { muscle } \\
\text { - HFD-treated mice } \\
\text { - KKAy mice } \\
\text { - MI in mice and rats } \\
\text { - SHRs rats }\end{array}$ & $\begin{array}{l}\text { - Hypertension } \\
\text { - CAD } \\
\text { - T2DM } \\
\text { - Stable angina } \\
\text { pectoris } \\
\text { - MI }\end{array}$ & [84-93] \\
\hline
\end{tabular}

$\uparrow$ increase, $\downarrow$ decrease. BPF, Bergamot Polyphenolic Fraction; METC, Mitochondrial Electron Transport Chain; ATP, Adenosine Tri-Phosphate; AMPK, 5' Adenosine Monophosphate-activated Protein Kinase; eNOS, endothelial Nitric Oxide Synthase; H0-1, Heme oxygenase 1; LV, Left Ventricular; 3-NT, Nitrotyrosine; MDA, Malonildialdehyde; Nox2, NADPH oxidase-2; VLDL-C, Very Low Density Lipoprotein Cholesterol; LDL-C, Low Density Lipoprotein Cholesterol; HDL-C, High Density Lipoprotein Cholesterol; TC, Total Cholesterol; SBP, Systolic Blood Pressure; DBP, Diastolic Blood Pressure; TG, Triglycerides; pCEH, pancreatic Cholesterol Ester Hydrolase; SOD, Superoxide Dismutase; SMC, Smooth Muscle Cells; LOX-1, Lectin-type Oxidized LDL receptor 1; PKB, Protein Kinase B; ROS, Reactive Oxigen Species; TBARS, Thiobarbituric Acid Reactive Substances; 8OHdG, 8-Hydroxy-2'-deoxyGuanosine; GPx, Glutathione Peroxidase; CK-MB, Creatine kinase isoenzyme; GSSG, Glutathione disulfide; LDH, Lactate Dehydrogenase; ET-1, Endothelin-1; IL-1 $\beta$, Interleukin-1 $\beta$; IL, Interleukin; TNF- $\alpha$, Tumor Necrosis Factor- $\alpha$; PCr, Phospho-Creatine; iNOS, inducible Nitric Oxide Synthase; Prdx, Peroxiredoxin; GSH, Glutathione; GS3K- $\beta$, Glycogen Synthase Kinase- $\beta$; Sirt-1, Sirtuin-1; FOXO3a, Forkhead box O3a; ERK1/2, Extracellular signal-Regulated Kinase 1/2; IkB $\alpha$, nuclear factor of kappa light polypeptide gene enhancer in B-cells Inhibitor- $\alpha$; STAT-3, Signal Transducer and Activator of Transcription 3; CYP2E1, Cytochrome P450 Family 2 Subfamily E Member 1; NF-kB, Nuclear Factor kappa-light-chain-enhancer of activated B cells; COX-2, Cyclooxygenase-2; GRP78, Glucose-Regulated Protein 78; CHOP, C/EBP Homologous Protein; ox-LDL, oxidized-Low Density Lipoprotein; HbA1c, glycated Haemoglobin; GLUT, Glucose Transporter; Bcl-2, B-cell lymphoma 2; Bcl-xL, B-cell lymphoma-extra large; JNK-1, c-Jun Nterminal Kinase; IDH, Isocitrate Dehydrogenase; SDH, Succinate Dehydrogenase; MDH, Malate Dehydrogenase; $\alpha$-KGDH, $\alpha$-Ketoglutarate Dehydrogenase; NADH, Nicotinamide Adenine Dinucleotide; CCO, Cytochrome C Oxidase; GPx, Glutathione Peroxidase, CAT, Catalase; SGOT, Serum Glutamic Oxaloacetic Transaminase; SGPT, Serum Glutamic Pyruvic Transaminase; PTP, Permeability Transition Pore; HIF- $1 \alpha$, Hypoxia-Inducible Factor 1- $\alpha$; OPA1, Optic atrophy Protein-1; Mfn, Mitofusin 1; Drp1,Dynamin-related protein 1; Fis1, mitochondrial Fission 1 protein; Bax, Bcl-2-like protein 4; Bad, Bcl-2 associated agonist of cell death; MCP-1, Monocyte Chemoattractant Protein-1; ECG, electrocardiogram; PCG1 $\alpha$, Peroxisome proliferator-activated receptor gamma Coactivator 1 alpha; PAI-1, Plasminogen Activator Inhibitor; Hs-CRP, High sensitivity C-Reactive Protein; ANP, Atrial Natriuretic Peptide; LC3, Microtubule-associated protein 1A/1B-light chain 3; mTOR, mechanistic Target Of Rapamycin; EPCs, Endothelial Progenitor Cells; HF, Heart Failure; eCSCs, endogenous Cardiac Stem Cells; Doxo, Doxorubicin; VPCs, Vascular Progenitor Cells, ISO, Isoproterenol; MI, Myocardial Infarction; I/R, Ischemia/Reperfusion; T2DM, Type 2 Diabete Mellitus; STD, Streptozotocin; TPA, 12-O-tetradecanoylphorbol-13-acetate; RNS, Reactive Nitrogen Species; AAP, acetaminophen; HFD, High Fed Diet; HFrEF, Heart Failure with reduced Ejection Fraction; MetS, Metabolic Syndrome; CHD, Chronic Heart Disease; CAD, Coronary Artery Disease.

Therefore, although the use of nutraceutical supplementation is of interest in the prevention and treatment of cardiovascular disease, the potential for its use in the treatment of HF still needs to be adequately assessed. More studies are required to verify the optimal use of nutraceutical supplementation in counteracting myocardial dysfunction in HF patients.

The aim of this review article is to assess the pathophysiological mechanisms involved in the early stages of HF and the potential for timely nutraceutical supplementation to support the failing myocardial cells in tandem with the pharmacological and nonpharmacological interventions currently being used. Moreover, a further objective is to 
optimise nutraceutical intervention through the identification of candidate natural extracts to be used in future clinical studies in patients experiencing HF.

\section{Emerging Pathophysiological Mechanisms Involved in the Onset of HF}

\subsection{Energy Deficiency and Mitochondrial Impairment in HF}

In patients with $\mathrm{HF}$, energetic deficits are palpable and can be detected, both in vivo and in vitro, in the early stages of the disease [94]. In particular, it has been reported that non-invasive measurement of the myocardial phosphocreatine $(\mathrm{PCr})$ via 31P-magnetic resonance spectroscopy (MRS) and an assessment of the PCr to adenosine triphosphate (ATP) ratio indicate an energy shortage, which is associated with many cardiac disease states, including ischemic heart disease and cardiomyopathies [95]. In this context, the degradation of ATP, which is frequently associated with diastolic dysfunction, represents a biomolecular target of $\mathrm{HF}$ with a preserved ejection fraction $(\mathrm{HFpEF})$ and indicates the occurrence of an increased energetic demand and/or energetic mismatch in HF [96-101]. This occurs at the early stages of the disease, thereby showing that counteracting the energy deficit may be crucial in the development of HF, though the mechanisms of energy impairment need to be better assessed.

Several studies, ranging from those conducted 50 years ago at the National Institute of Health (NIH) to more recent studies [102-105], have suggested that the electron transport chain (ETC) function is not impaired in failing versus not-failing hearts, although conflicting data exist [106]. Studies on the role of Krebs cycle activity, which is responsible for the production of nicotinamide adenine dinucleotide (NADH) and flavin adenine dinucleotide (FADH2) from acetyl-coenzyme A, have shown an impairment of this energy-producing pathway in decaying hearts [104,107]. This effect is accompanied by an impaired spatial pattern, which characterises mitochondria within cardiac cells. In particular, energy depletion affects mitochondrial functionality. This is shown by the expression of a class of fusion proteins, such as mitofusins (Mfn1 and Mfn2), which also potentially affect the Sarcoplasmic Reticulum (SR)-mitochondrial $\mathrm{Ca}^{2+}$ microdomain [108-110], and this, in turn, is accompanied by dysregulation of the mitochondrial $\mathrm{Ca}^{2+}$ uniporter (MCU), seen by means of a mouse model of pressure overload [111].

Together, these data indicate that in $\mathrm{HF}, \mathrm{Ca}^{2+}$-induced stimulation of the Krebs cycle is impaired by decreased mitochondrial $\mathrm{Ca}^{2+}$ uptake during cardiac workload transitions.

Mitochondrial functionality is also crucial in the balance between energy production and the consistent anti-oxidative capacity of failing cardiomyocytes [112,113]. In particular, it is well-known that the oxidation of NADH, which occurs during an elevated cardiac workload, is an important consequence of this energy supply and demand mismatch [114]. The depleted NADPH-coupled anti-oxidative capacity is then overwhelmed by reactive oxygen species (ROS) production by NADH-coupled respiration in the electron transport chain (ETC) $[115,116]$. Consequently, this favours the reverse mode of the mitochondrial nicotinamide nucleotide transhydrogenase (Nnt), thus dissipating the anti-oxidative capacity [115]. Aon et al. proposed that "mitochondria have been evolutionarily optimized to maximize energy output while keeping ROS overflow to a minimum by operating in an intermediate redox state" [116].

Therefore, extreme oxidation, as aforementioned, and a reduction in the mitochondrial redox state, such as that which occurs during ischaemia, are to be avoided in order to achieve optimal conditions for cardiac mitochondria. However, the working heart constantly produces adenosine diphosphate (ADP), physiologically accelerating respiration and increasing oxidation in the respiratory chain. Therefore, it is unlikely that increased oxidative stress in HF is solely due to a net increase in ROS production, but rather due to a diminished ROS-scavenging capacity [117]. This leads to a vicious circle, increasing oxidative stress by exacerbating the mismatch in the energy supply and demand [118]. Mitochondria contain unsaturated fatty acids, iron sulphur clusters, densely packed proteins, and multiple copies of mitochondrial DNA (mtDNA), all of which are essential to the mitochondrial function and typical targets of oxidative damage [119]. The most vulnerable 
to oxidative damage, due to their proximity to ROS production, are the ETC complexes, which include cardiolipin [120]. Moreover, oxidative stress triggers the peroxidation of cardiolipin, thereby impairing cristae formation [121]. On the other hand, the respirasome and the detachment of cytochrome $\mathrm{c}$, which is a mobile electron carrier in the inner mitochondrial membrane (IMM), are also affected by the peroxidation of cardiolipin [122]. Mitochondrial DNA is associated with the IMM and vulnerable to oxidative damage due to the lack of protective histones. Furthermore, damage to mtDNA results in ATP synthesis reduction, reduced ETC activity and a further increase in electron slippage to oxygen, thus setting up a feed-forward cycle of ROS-induced ROS production [123-125]. Hence, at the centre of an efficient cardio-protection strategy, in the early stages of HF, is the preservation of the functionality of the mitochondria in cardiomyocytes, which represents a consistent challenge.

\subsection{Endoplasmic Reticulum Stress in HF}

As previously shown for the role of mitochondrial dysfunction, stressful conditions occurring at the level of the endoplasmic reticulum (ER) stress also seem to play a crucial role during the early phases of HF [126-128]. In particular, there is evidence that ER impairment is accompanied by enhanced oxidative stress which, in turn, is connected to various cardiovascular conditions, such as cardiac hypertrophy and, at the late stages, HF $[129,130]$.

ER and mitochondria are capable of regulating oxidative stress. In particular, in models of heavy-metal-induced myocardial dysfunction, an increase in the level of stress markers of ER occurs. This implies that oxidative stress and heart dysfunction are connected to extreme ER stress. Moreover, data have shown that when induced by excessive ER stress, protein damage and intracellular calcium ion $\left(\mathrm{Ca}^{2+}\right)$ anomalies trigger heart dysfunction $[130,131]$. Several toxicants potentially contribute to heart injury via this mechanism. The effect of these toxicants can be counteracted by natural antioxidants which efficiently revive ER stress levels in the heart. Hence, by regulating the ER-related pathway, natural antioxidants can exert a protective role against cardiotoxic agents via a significant reduction in ER stress. The mechanism of cardioprotection obtained by means of natural antioxidant supplementation can possibly be explained by regulation of the ER-related pathway. In particular, it has been found that ER and oxidative stress lead to impairment of the so-called unfolded protein response (UPR), which is a compensatory mechanism that contributes to maintenance of the myocardial cell integrity. This involves complex molecular pathways, probably driven by eukaryotic translation initiation factor 2 alpha (eIF2 $\alpha$ ) phosphorylation and protein kinase RNA-like ER Kinase (PERK) and leading to a compensatory response to ER stress, although this needs to be better clarified [130-136]. Furthermore, an increase in intracellular Glucose-Regulated Protein 78 (GRP78), considered to be a chaperone of ER stress and, most importantly, a regulator of UPR, has been shown to play a role in these mechanisms [132-136].

Therefore, it is likely that active ingredients of plant extracts, once given at an appropriate dosage and formulated to obtain the due concentration at the active site of action, may produce a beneficial effect to counteract cardiomyocyte ER stress.

\subsection{Imbalanced Metalloproteinase Regulation in HF}

The extracellular cardiac matrix (ECM), which is a complex architectural network, maintains a balance between the degradation and deposition of matrix proteins by preserving the correct cardiac geometry whilst also allowing the myocardium to maintain its structural integrity [137]. The ECM aids in the proper functioning of heart cells, forming a specific scaffold which allows for the anchoring of these proteins [138]. A range of physiological and pathological processes, such as cell proliferation and differentiation, and tissue morphogenesis, are influenced by the ECM turnover [139]. The ECM is also responsible for the transduction of mechanical forces within the cardiac vessels and heart, and for promoting diastolic compliance in the arterial wall. 
Matrix metalloproteinases (MMPs) are enzymes capable of degrading both of the ECM structural proteins being modulated by metalloproteinase endogenous tissue inhibitors (TIMPs). These are the fundamental mediators of ECM remodelling. In normal circumstances, these processes are highly regulated. The roles of MMPs and TIMPs can be both positive and negative in cardiac remodelling [138,139], with TIMPs controlling MMPs, minimising the degradation of the matrix. The MMPs play a pathological and irreversible role in remodelling ECM, which is important in both compensatory cardiac hypertrophy and acute decompensated heart failure [140]. MMPs also mediate the ventricular remodelling caused by myocardial infarction or viral myocarditis [140]. Several studies indicate that the serum level of metalloproteinase-2 (MMP-2) is an autonomous predictor of mortality in HF patients [141]. MMPs are made up of five main groups, including gelatinases, collagenases, matrilysins, stromelysins, and metalloproteinases of membrane-type/membrane-type MMPs. The divisions of these groups are based upon their structure and the specificity of the substrate [142]. Two of these-Gelatinase A and Gelatinase B, (also known as MMP-2 and MMP-9, respectively) — are directly involved in the pathogenesis of coronary thrombosis, atherosclerosis, myocardial infarction, and heart failure [143]. Furthermore, MMP-2 causes migration of the cell, growth, differentiation, and inflammation [144]. These enzymes cleave structural proteins from the elastin and collagen networks. The known spectrum of substrates for MMP-2 not only contains the components of extracellular matrixes, such as collagens or elastin, but MMP-2 is also able to digest parts of the contractile apparatus, such as the myosin 1 light chain or troponin I [143]. It has been proven that, during ischaemia, the proteolytic function of MMPs in myocardium generally increases. Moreover, alterations in the balance of MMPs and TIMPs could contribute to acute myocardial ischaemia-reperfusion injury [145]. Conversely, MMP-2 is associated with myocardial dysfunction, contributing to the development of cardiomyopathies [146-150]. The occurrence of an imbalanced regulation of the NT-truncated intracellular isoform of MMP-2 (NT-MMP-2) as a consequence of mitochondrial dysfunction and oxidative stress seems to be involved in myocardial injury [151,152]. Due to the strong connection between NT-MMP and the mitochondria, it is likely that pathophysiological events, subsequent to hyperglycaemia, may underlie a cascade of events mediated by oxidative stress which are associated with mitochondrial dysfunction [152-154]. These events cause an altered modulation of MMPs and, at the end stage, lead to failing myocardium, such as that which can be seen in the hearts of diabetic patients.

Recently, we examined an exaggerated production of superoxide anion (NADPH oxidase-dependent), which occurs in hyperglycaemic rats, gradually impairing the function and myocardial structure [155]. In particular, we found that during the initial stage of cardiac injury brought on by chronic hyperglycaemia, the reduced fractional shortening and ejection fractioning are associated with biochemical changes, suggesting the involvement of mitochondrial functionality. In particular, in a model of streptozotocin (STZ)-induced hyperglycaemia, we found that increased ROS production is accompanied by an increased expression of the mitochondrial translocator protein (TSPO): a protein located at the level of the outer mitochondrial membrane [154-156] which has been found to be imbalanced in post-ischemic cardiac damage [157]. Moreover, STZ-induced hyperglycaemia is associated with an increased expression of selective Voltage-Dependent Anion Channel-1 (VDAC1), which contributes, alongside TSPO, to the regulation of calcium traffic at the level of the transition pore of the mitochondrial membrane. Under these experimental conditions, MMP-2 was downregulated and NT-MMP2 was found to translocate at the level of the mitochondrial membrane, thereby suggesting that these mechanisms could contribute to functional changes seen in the heart of hyperglycaemic rats. These effects may be counteracted by natural antioxidants (see below).

\subsection{The cGMO/NO Pathway in HF}

There is evidence that, through important roles in the cardiac myocyte, nitric oxide (NO), nitric oxide synthase (NOS), and soluble guanylate cyclase (sGC) all oppose patho- 
logical remodelling when functioning normally [158]. A large body of work supports that in $\mathrm{HF}$ and in conditions predisposing to HF, NO, which is the activator of soluble guanylate cyclase, also becomes dysregulated [159]. The cardiovascular tissue release of NO can be directly reduced by ROS in the absence of effects on NOS expression and activity [159]. Correspondingly, human studies have shown that there is a predisposition to HF in conditions associated with reduced endothelial NO release. These reduced endothelial NO release conditions include ageing, diabetes, and obesity [160]. In fact, based on these human data, a current proposed model postulates that the pathogenesis of HFpEF is driven by the generation of reduced NO-induced cyclic guanosine monophosphate (cGMP) [161,162]. Animal models have also shown that endothelial nitric oxide synthase (eNOS) becomes uncoupled not only in hypertension [163], but also in a pressure overload stress model [164]. This promotes the production of pathologic reactive oxygen species (ROS), rather than NO. Additionally, under conditions of oxidative stress and multiple HF risk factors, soluble guanylate cyclase can be directly modified and rendered unable to generate cGMP in response to NO. In fact, in a pressure-overload stress model, it has been reported that the translocation of sGC is involved in sGC oxidation and contributes to depressed NO-stimulated sGC activity [164].

Moreover, the failing heart not only exhibits changes in cGMP catalysis through the upregulation of cGMP-specific phosphodiesterases (PDEs), but also alterations in sGC augmentation. Part of an 11-member family, PDEs (PDE1 to PDE11) catabolise cAMP, cGMP or both, depending on the specific PDE [165]. Recently, PDE5 and PDE9, both of which are cGMP-specific PDEs, have been studied. According to samples taken from endstage failing myocardium, PDE5 expression increased in the failing human left ventricular (LV) [166]. Furthermore, in the LV of mice subjected to experimental transverse aortic constriction (TAC), aside from protein expression, the total cGMP phosphodiesterase activity increased [167]. Studies on pharmacological and genetic manipulation in mice have also confirmed the pro-remodelling role of the enzyme in the cardiomyopathies and the effectiveness of PDE5 inhibition in opposing cardiac remodelling [165]. More recently, in the failing human LV, an increase in the cGMP-selective PDE9 was observed in both Reduced as well as Preserved Ejection Fraction Heart Failure (HFrEF and HFpEF, respectively). This was observed in the LV of mice subjected to TAC as well. After thoracic or abdominal aortic constriction, as well as in response to isoproterenol infusion, genetic deletion or pharmacological inhibition of PDE9, LV remodelling improved [168,169].

The aforementioned observations describe a general model in which alterations in components of both cGMP-generating and anti-cGMP-generating components lead to a net reduction in myocardial cGMP, subsequent cardiac remodelling and failure. Studies on the myocardial tissue of HFpEF patients, compared with that of not-failing tissue patients with aortic stenosis or with HFrEF tissue, have demonstrated a reduced cGMP concentration [170]. Reduced myocardial cGMP has also been observed in a rat model of HFpEF [171], and tissue from patients display increased PDE9A and cGMP-esterase activity [170]. On the other hand, in the presence of PDE5 and PDE9 inhibition, numerous animal studies have also identified a net increase in cGMP $[168,169]$. Therefore, the rationale behind pharmacological and nutraceutical strategies to augment intracellular cGMP in patients with HF is supported by animal studies of cGMP regulating molecules and direct observations in humans with HF.

\subsection{HF and Sodium-Glucose Cotransporters}

Evidence has been provided demonstrating that sodium-glucose cotransporter (SGLT2) inhibitors may produce benefits in cardio-renal dysfunction in diabetic patients. This has been assessed by means of an extensive review by Verma and McMurray reporting large-scale clinical trials of type 2 diabetes mellitus (T2DM) patients with either multiple cardiovascular risk factors or established cardiovascular disease [172].

In particular, it has been reported that many of the potential benefits of regulating SGLT2 in both diabetic and non-diabetic patients with HF have been attributed to the 
slowing of the atherothrombotic processes which accompany type 2 diabetes mellitus (T2DM), and the improvement in the cardio-renal consequences of T2DM, which can lead to myocardium decay. Moreover, recent evidence suggests that SGLT2 modulation is accompanied by additional effects which may be beneficial to HF management. In particular, it has been postulated that SGLT2 inhibitors may improve and/or optimise cardiac energy metabolism.

These agents may provide improvement in the cardiac output and cardiac efficiency by acting on the substrate efficiency and myocardial energetics [172]. Furthermore, in the presence of T2DM and/or HF, it has been suggested that the metabolic flexibility of the heart is impaired as it relates to substrate utilisation [173].

A build-up of free fatty intermediates may result from an over-reliance on nonesterified fatty acids (NEFAs) as a substrate for ATP generation. This action may also promote the development of diastolic dysfunction and lipotoxicity [174].

In those with diabetes, SGLT2 inhibitors may offer an optimal alternative myocardial fuel source [175]. This alternative fuel source is more cost-effective in those with T2DM, as SGLT2 inhibitors are known to promote ketone body $\beta$-hydroxybutyrate $(\beta \mathrm{OHB})$ production [176]. It has been postulated that elevated ketone levels may be the result of an effort to increase glucagon levels through a possible decrease in $\beta \mathrm{OHB}$ excretion via the kidneys. The concept underlying this is that ketone-body $\beta \mathrm{OHB}$ is a "super fuel", oxidised by the heart instead of glucose and NEFAs. In the failing heart, ketones may improve the cardiac function and increase the mechanical efficiency $[177,178]$. This is an interesting postulate, although cogent data supporting this thesis are scarce. Preliminary studies carried out in pigs following myocardial infarction showed that empagliflozin increases the consumption of myocardial ketone while simultaneously reducing the production of lactate, as well as the consumption of cardiac glucose [179]. Another hypothesis is that this is due to the inhibition of histone deacetylase, promoting increases in the levels of SGLT2-inhibitor-induced $\beta \mathrm{OHB}$ and preventing pro-hypertrophic transcription pathways [180].

It is also possible that a decrease in $\beta \mathrm{OHB}$ oxidation promotes a decrease in acetyl-CoA, which is a derivative of ketone oxidation. These decreased levels, in turn, increase glucosederived pyruvate oxidation and thus improve myocardial glucose metabolism. A decrease in the supply of acetyl-CoA may result in an improved production of mitochondrial energy and, consequently, in a decrease in the harmful hyperacetylation, thus aiding the mitochondrial enzymes [180].

It has been postulated, using an untargeted metabolomic approach, that the inhibition of SGLT2 promotes the degradation of branched-chain amino acid (BCAA), which may provide an alternative source of fuel to the failing myocardium. In HF patients, the impaired degradation of BCAA in myocardium may contribute to aberrant bioenergetics [181]. As intriguing as these findings are, it must be noted that we currently lack definitive evidence that links the beneficial effects of SGLT2 inhibition to myocardial energetics.

A promising emergent hypothesis is that direct inhibition of the $\mathrm{Na}+\mathrm{H}+$ exchanger (NHE) 1 isoform in the myocardium may be an effect of SGLT2 inhibition and consequential effects on $\mathrm{Na}+/ \mathrm{H}+$ exchange in the myocardium $[182,183]$.

In experimental models of HF, it has been demonstrated that NHE1 activation results in increased cytosolic sodium and calcium. Recently, Ulthman et al. demonstrated that the cardiomyocyte NHE is inhibited by the SGLT2 inhibitor empagliflozin, thereby increasing mitochondrial calcium levels while reducing the levels of cytoplasmic sodium and calcium [183].

In the heart, the mechanism by which these effects occur on cardiomyocyte NHE remains elusive, as SGLT2 receptors are not expressed. Notably, it has been suggested that natriuresisis is promoted in the proximal tubule by SGLT2 inhibitors, which downregulate the NHE3 activity [184]. In HF patients, the expression of NHE3 is increased and known to mediate the reuptake of tubular sodium. As an additional mechanism, the inhibitory effects on NHE3 may serve to reduce cardiac failure and restore whole-body sodium homeostasis. 
Hence, prevention and/or treatment of HF may be possible by these agents through a common cardio-renal mechanism, such as the inhibition of NHE1 and NHE3 [182].

Cardiac fibrosis and SGLT2 inhibition are widely regarded as common final pathways through which HF develops. Cardiac structural remodelling is universally involved in this mechanism due to the deposition of ECM proteins by cardiac fibroblasts, which accelerate the development of HF by impeding ventricular compliance [185]. Recent experimental data on myocardial infarction showed the significant cardiac anti-fibrotic effects of dapagliflozin on the suppression of collagen synthesis, an effect made possible by the increased activation of M2 macrophages and inhibition of myofibroblast differentiation [186]. Additionally, preliminary studies, using human cardiac fibroblasts measured by the collagen fibre alignment index, have demonstrated that empagliflozin significantly attenuates the activation of TGF- $\beta 1$-induced fibroblasts while reducing cell-mediated ECM remodelling [187]. Moreover, evidence demonstrates that empagliflozin suppresses the expression of multiple key pro-fibrotic markers, including type I collagen, $\alpha$-smooth muscle actin, the connective tissue growth factor, and MMP-2 [187]. Therefore, an emerging postulate is that the inhibition of SGLT2 may have direct and favourable effects on one of the most important factors of HF-the cardiac fibroblast phenotype and function. These effects indicate potential for using nutraceutical supplementation with natural SGLT2 inhibitors, such as a phlorizin-rich apple extract.

\subsection{Impairment and Senescence of Cardiac Stem Cells in HF}

It is known that myocardial infarction and ischaemic heart disease are the major determinants for the development of HF $[188,189]$. Furthermore, where HF is of a nonischaemic origin, in cases of structural and "functional" cardiomyopathies, the lack of myocardium is the primary issue to be addressed for a robust cardiomyocyte replacement $[190,191]$. Regenerative medicine aims to find a therapy that is both effective and broadly available to refresh the contractile muscle cells lost and/or rendered permanently dysfunctional as a consequence of the primary injury $[190,191]$. Unfortunately, the predominant scepticism about the intrinsic endogenous regenerative capacity of the adult mammalian heart, including the human heart, has produced often contradictory approaches in myocardial repair/regeneration [191]. This skepticism can only be overcome if hard, clean and clear scientific data are obtained, thereby eliminating the need for interpretations and opinions. It is unlikely that any clinical repair or regeneration protocol will ever be able to answer the question regarding the feasibility of functionally regenerating the failing human heart [191]. It is well-known that the mammalian heart, including the human heart, contains a pool of resident tissue-specific cardiac stem/progenitor cells-the endogenous Cardiac Stem Cells (CSCs) - referred to as eCSCs when in the myocardium, and CSCs when isolated and studied in vitro [192-194]. The eCSCs have been identified as a small cardiac cell population through the expression of specific membrane markers, in particular, the stem cell factor (SCF) receptor kinase c-Kit [195], Sca-1 [196], and MDR-1 [197]. In vitro and in vivo experiments have clearly shown that CSCs, being multipotent, clonogenic, and self-renewing, have all the characteristics expected of a tissue-specific stem cell. Differentiation of the main myocardial cell is possible in vivo and in vitro [192]. Several studies have reproduced the findings that while the exhibition of c-Kit cell dysfunction is present in W locus mouse mutants (W/Wv) [198], c-Kit signalling in vitro promotes the survival, growth, and proliferation of human CPCs [199]. Indeed, W/Wv mice display impaired cardiac recovery after infarction [200], diminished cardiac function with advanced age [201], and compromised c-Kit cell differentiation into cardiomyocytes [202]. Blunted reparative responses were exhibited in both myocardial injuries in bone marrow c-Kit ${ }^{\text {pos }}$ cells from $\mathrm{W}$ locus mutants and in vitro cells with silenced c-kit [198].

Furthermore, deletion of the c-Kit gene, as it occurs in homozygous W-mutated mice [200], causes premature murine death, because c-Kit gene deletion is incompatible with life. However, during embryonic life, c-Kit-defective adult mouse hearts appear to develop normally [203], while adult myocardial infarction model c-Kit Cre-KI mice have 
demonstrated a significant defect in the regeneration potential [204]. Therefore, it appears that the roles that c-Kit plays in cardiac regeneration are different to those it plays in heart formation/development. This suggests that the molecular mechanism underlying cardiac regeneration differs from that of cardiac generation. Despite all of the attempts that are currently ongoing to decode the pathways of developmental cardiac generation and neonatal heart regeneration to instruct effective protocols of adult cardiac regeneration, cardiac generation has still not been predicted [205]. Finally, the role of c-Kit in cardiac pathology was evaluated in several models, such as aging cardiomyopathy [206,207], doxorubicininduced cardiomyopathy [208], and chronic heart failure [209,210]. In particular, Huang et al. developed a "paediatric" model of doxorubicin-induced cardiotoxicity, in which juvenile mice were exposed to doxorubicin (DOXO) using a cumulative dose that did not induce acute cardiotoxicity [211]. These juvenile mice developed normally and had no obvious cardiac abnormalities as adults. However, these hearts did have reduced numbers of c-Kit ${ }^{\text {pos }}$ cardiac cells and abnormal vasculature, which correlated with an increased sensitivity to stimuli, both physiological and pathological. When subjected to myocardial infarction, adult mice developed a more pronounced cardiac decompensation, which correlated with a failure to increase the capillary density in the injured area. It was subsequently demonstrated that DOXO-induced cardiomyopathy is due to a depletion of the functional c-Kit ${ }^{\text {pos }} \mathrm{CSC}$ pool, and can be rescued by restoring its function via nutraceutical supplementation [212].

\section{Candidates for Nutraceutical Supplementation in the Failing Myocardium according to the Aforementioned Emerging Mechanisms}

\subsection{Coenzyme $Q 10$}

Coenzyme Q10 (CoQ10), also defined as ubiquinone (in the oxidised form) or ubiquinol (in the reduced form), plays a key role in the functioning of the MC. CoQ10 is responsible for the transfer of electrons from complex I and II to complex III, thus promoting ATP generation [213] (Figure 1). Moreover, CoQ10 is involved in the so-called proton motive Q-cycle, which enables the passage of protons across the internal mitochondrial membrane [214]. Q10 has a highly lipophilic molecular structure and is related to vitamin $K$, where " $Q$ " represents quinone and "10" refers to the 10-isoprene group. [215]. CoQ10 is ubiquitous in most mammalian tissues, with particularly high levels in organs, such as the heart, with the highest rate of metabolism [215]. The higher concentration of CoQ10, compared to other carriers, balances its slower cyclic oxidation/reduction rate [30]. Therefore, CoQ10 deficiency in the cardiac mitochondria leads to the dysfunction of mitochondrial respiration. Conversely, CoQ10 supplementation could improve the mitochondrial function [18]. Preclinical data suggest that CoQ10 has important anti-inflammatory properties and is able to protect endothelial function from damage [19]. In fact, CoQ10 also regulates eNOS function in different cellular membranes. Therefore, the depletion of CoQ10 can promote the uncoupling of eNOS, making it an additional source of ROS and thereby shifting the nitrous-redox balance towards oxidation [20].

Interestingly, data have demonstrated a protective role of CoQ10 in high glucoseinduced endothelial progenitor cell (EPC) dysfunction [31]. In particular, the administration of CoQ10 reduces apoptosis cell death and increases the mitochondrial membrane potential. In addition, CoQ10 is able to reduce ROS production, enhancing eNOS/Akt activity and upregulating HO-1 expression [31] (Figure 2). 


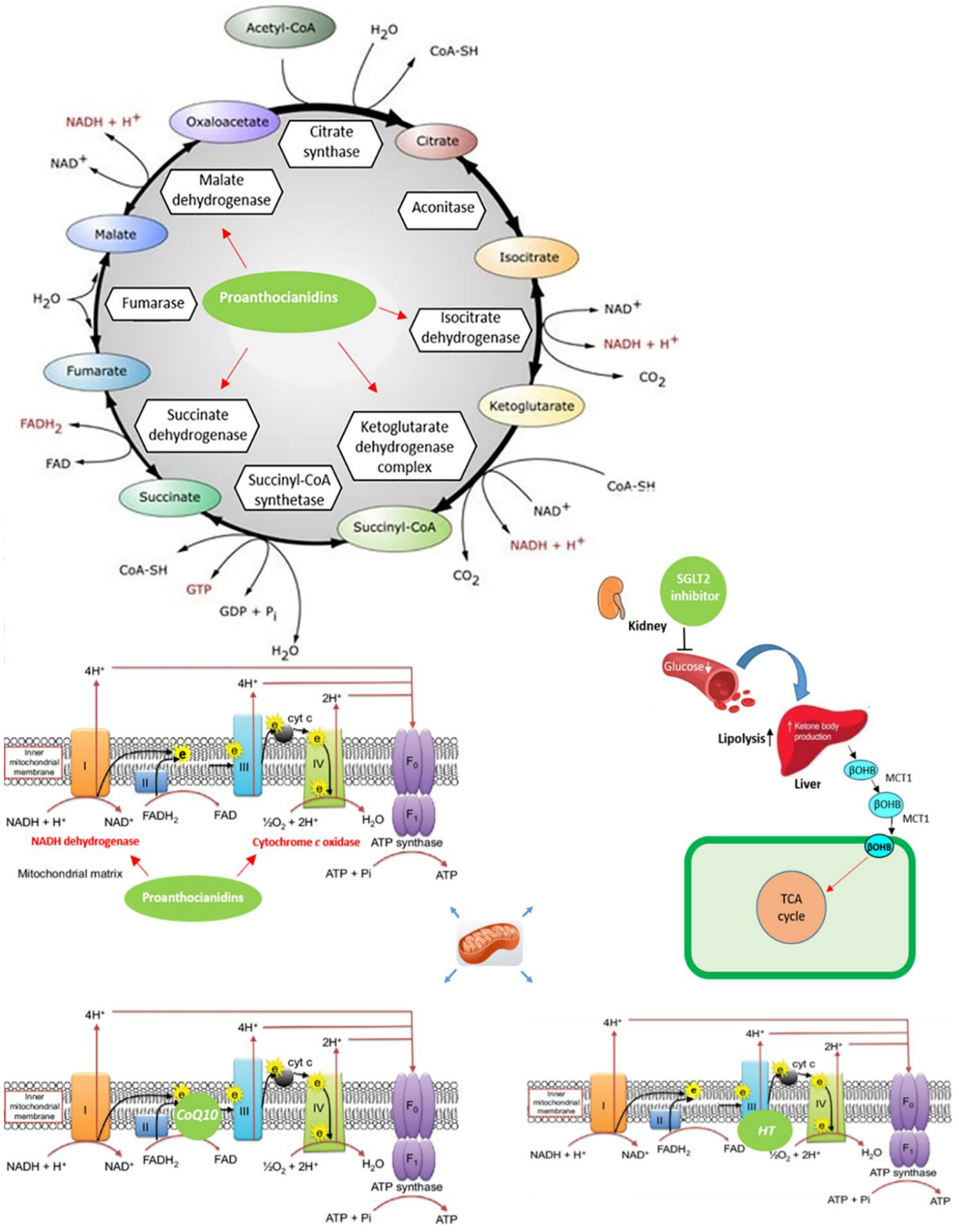

Figure 1. Effects of nutraceuticals on the mitochondrial function in heart diseases. Coenzyme Q10 (CoQ10) plays a critical role in adenosine triphosphate (ATP) generation by accepting electrons from complexes I and II and transporting them to complex III of the mitochondrial electron transport chain. Moreover, CoQ10 is involved in the protons' transfer in the inner mitochondrial membrane, called the proton motive Q-cycle, leading to the free movement of protons through the internal mitochondrial membrane; sodium-glucose cotransporter (SGLT2) inhibitors increase the amount of ketone bodies; proanthocyanidins significantly increase the activities of mitochondrial enzymes (isocitrate dehydrogenase, succinate dehydrogenase, malate dehydrogenase and $\alpha$-ketoglutarate dehydrogenase) and respiratory chain enzymes (nicotinamide adenine dinucleotide (NADH) dehydrogenase and cytochrome c oxidase); hydroxytyrosol (HT) is able to improve the integrity of complex-III of the mitochondrial electron transport chain. 


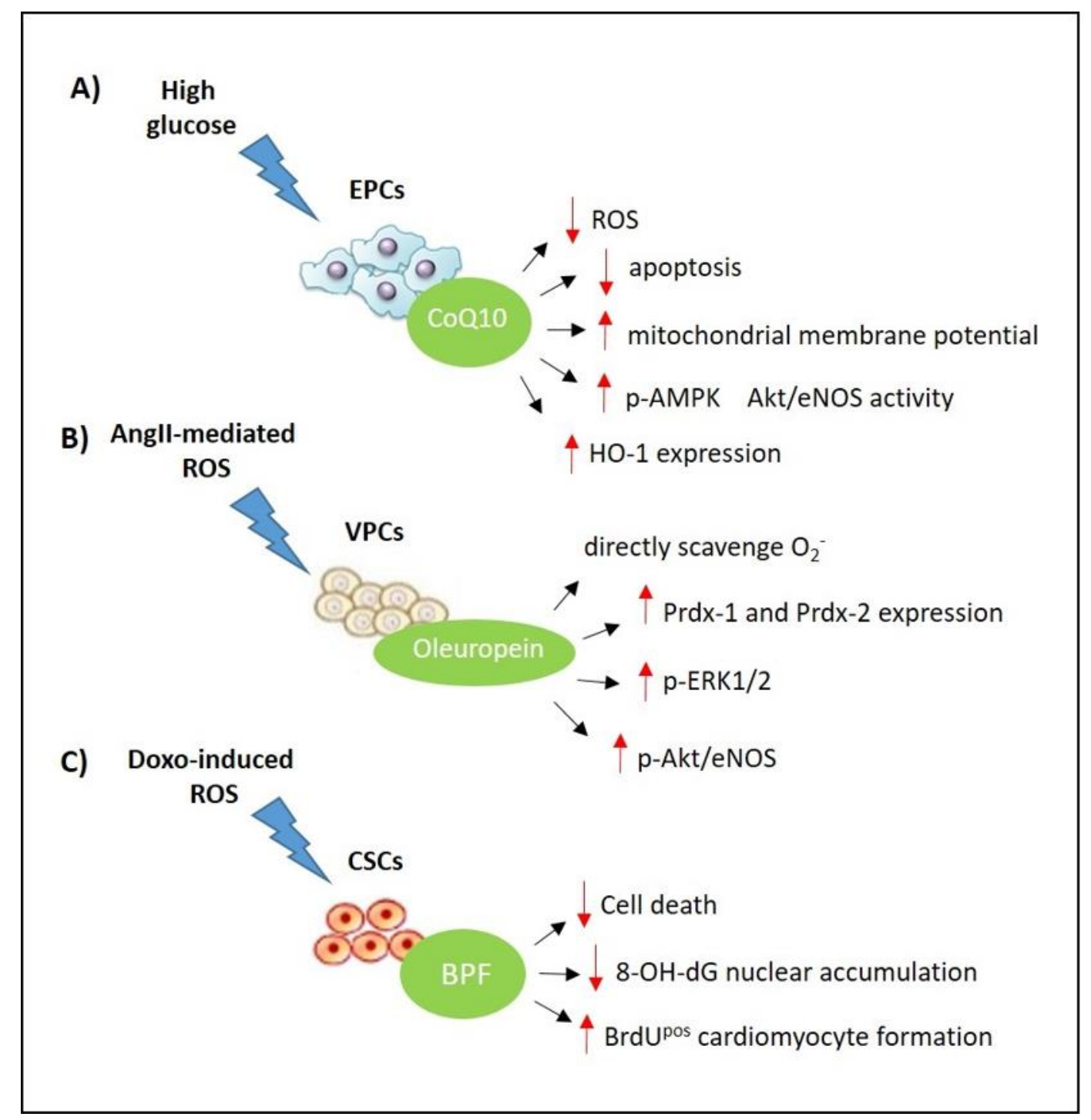

Figure 2. Effects of nutraceuticals on the stem cell compartment in heart diseases. (A) CoQ10 inhibits high glucose-induced endothelial progenitor cell (EPC) dysfunction and death via modulation of the $5^{\prime}$ adenosine monophosphate-activated protein kinase (AMPK) pathway, upregulating endothelial nitric oxide synthase (eNOS) activity and heme oxygenase-1 (HO-1) expression; (B) oleuropein attenuates AngII-mediated oxidative stress in vascular progenitor cells (VPCs) though direct scavenging activity and regulates the ERK1/2-Prdx and Akt/eNOS signalling pathway; (C) the bergamot polyphenolic fraction (BPF) protects endogenous CSCs against DOXO-induced cardiotoxicity though its direct antioxidant properties and stimulates CSC activation and differentiation in newly formed cardiomyocytes.

Physiologically, about $50 \%$ of CoQ10 is ingested, while the remaining $50 \%$ is endogenously synthesised through the mevalonate pathway, which is inhibited by a statin action [32]. Indeed, in isoproterenol-induced HF in rats, Garjani et al. showed a severe LV dysfunction when the animals were treated with a high dose of atorvastatin. Conversely, it has also been reported that the co-administration of CoQ10 with a lower dose of atorvastatin ameliorates myocardial necrosis and fibrosis and the hemodynamic depression, improving left ventricular (LV) dysfunction [33]. Hence, patients with a cardiovascular risk and/or disease treated with statins may experience CoQ10 deficiency [18]. In patients with $\mathrm{HF}$, the severity of disease is correlated with CoQ10 deficiency [34]. Experimental evidence suggests that lipid peroxidation, resulting from oxidative stress, causes a reduction in CoQ10 levels [35]. At first, in a preliminary clinical study conducted in patients with HF, CoQ10 was defined as an independent predictor of mortality [36]. However, this was not confirmed by the data obtained from the larger CORONA study. 
According to the results of the CORONA study, the treatment of patients with rosuvastatin failed to reduce nonfatal myocardial infarction, nonfatal stroke due to ischaemic cardiomyopathy, and the primary endpoint of death from cardiovascular causes [37]. However, the treatment of patients with rosuvastatin did reduce CoQ10 concentrations. Nevertheless, the administration of rosuvastatin in patients with a low baseline of CoQ10 did not lead to a worse outcome [37]. In accordance with this, CoQ10 deficiency was not considered an independent prognostic factor in HF [37]. In light of this evidence, CoQ10 deficit could play a causal role in patients suffering from HF, even those not treated with statins. CoQ10, as an established mitochondrial therapy, ameliorates CoQ10 biosynthesis defects through the constant dosing of CoQ10 dietary supplementation [38]. However, despite the lack of firm evidence of its benefit in cardiovascular diseases, CoQ10 supplementation has been studied for several decades. Though several clinical trials have shown that CoQ10 may enhance Left Ventricular Ejection Fraction (LVEF), other well-designed studies are needed to assess its effect on patient outcome [21]. Recently, in the Q-SYMBIO trial, the effects of CoQ10 were studied in 420 patients with systolic HF. The results showed a significant amelioration in symptoms and a substantial decrease in major adverse cardiovascular events [21]. However, the study was underpowered and failed to provide enough evidence of a benefit in this population. Therefore, it is still unclear whether CoQ10 administration benefits the outcome and symptoms in HF [21,22]. Moreover, in the recent guidelines on the treatment of HF, there is no mention of CoQ10 [19].

\subsection{Bergamot Polyphenols}

Evidence has been collected showing that bergamot fruit (both juice and albedo) produce beneficial effects in the cardiovascular system [24,39-44]. In fact, being rich in polyphenols, bergamot derivatives produce an antioxidant response both in vitro and in vivo, leading to a reduction in cholesterol, glucose and triglyceride serum levels, which is an effect accompanied by a reduction in systemic inflammation and, subsequently, an improvement in the endothelial function. These effects were confirmed in patients, mostly by means of a bergamot polyphenolic fraction (BPF) extract, which displayed a potent effect in modulating the liver traffic of lipoproteins and was able to counteract Non-Alcoholic Liver Disease (NAFLD). The major components of BPF are naringin, neoeriocitrin and neohesperidin and glycosylated polyphenols, such as bruteridin and melitidin, which have been found to produce the inhibition of 3-hydroxy-3-methyl-glutaryl Coenzyme A (HMGCoA) reductase $[23,25,45,46]$.

Recent data published by Carresi et al. have also shown that BPF treatment leads to relevant benefits in doxorubicin (DOXO)-induced cardiac damage in rats, preserving LV contractility and attenuating pathologic myocardial remodelling [212]. Intriguingly, our data show that BPF strongly prevented the induction of ROS, the excessive expression of pro-autophagic mediators, and myocyte apoptotic cell death. Moreover, there is evidence that $\mathrm{BPF}$ is able to attenuate attrition in cardiac-resident stem cells (eCSCs), promoting newly formed myocytes in DOXO-treated rats [212].

In fact, Carresi et al. showed, for the first time, that BPF is also able to attenuate attrition in endogenous cardiac stem cells (eCSCs), thereby improving the number of resident c- $\mathrm{Kit}^{\mathrm{pos}} \mathrm{CD} 45^{\text {neg }} \mathrm{CD} 31^{\text {neg }}$ eCSCs. On the other hand, BPF inhibited 8-hydroxy2 -deoxyguanosine $(8-\mathrm{OHdG})$ nuclear accumulation, and promoted the replenishment of cardiomyocytes with an increased number of small, newly formed BrdUpos myocytes after DOXO administration [212] (Figure 2). This fits with previous experimental evidence correlating DOXO-induced cardiac damage with stem cell impairment. Indeed, Burridge et al. showed, in patients with breast cancer undergoing DOXO-induced cardiotoxicity, that human-induced pluripotent stem-cell-derived cardiomyocytes are compromised by atrcaciclyne treatment [216]. In addition, it has recently been reported that the intravenous administration of cardiac progenitor cell-derived exosomes protects against doxorubicin/trastuzumab-induced cardiac toxicity [217]. 
Therefore, the main findings from the Carresi et al. study revealed the highly beneficial cardio-protective effects of BPF against DOXO-induced cardiomyopathy through its direct scavenging and antioxidant properties.

The antioxidant effect of BPF enables it to interfere with the production of DOXOinduced free radicals, excessive autophagy activation, and apoptosis, thus preventing the compensatory mechanisms and pathological changes that lead to the development of cardiomyopathy.

Overall, these data show a widely beneficial effect, highlighted by BPF, not only on cardiomyocytes, but also likely on the population of endogenous cardiac stem cells (eCSCs). These findings likely represent only part of the cardio-protective effects of bergamotderived polyphenols.

BPF has clear protective effects on the heart and is likely involved in the maintenance of functional endogenous cardiac stem cells. Even if some of the protective effects of BPF can be clearly attributed to its direct scavenging and antioxidant properties, the protective molecular mechanism involved in the maintenance of resident endogenous cardiac stem cells is not yet fully understood.

Further work is required to understand the specific molecular and genetic mechanisms underlying the onset of cardiomyopathy induced by DOXO and to confirm our findings on the role of BPF in cardio-protection.

\subsection{Olea Europea L. Extract}

Several studies credit the Olea Europaea leaf extract (OLEX) for the majority of the beneficial effects that the Mediterranean diet has on human health [218-222]. Initially, the richness of monounsaturated fatty acids (MUFA), and in particular that of oleic acid, was considered the major healthful characteristic of OLEX. Following other observations made for various aliments rich in MUFA, such as sunflowers, rapeseeds, and soybean, it is quite clear that none of those aliments are comparable to OLEX as healthy food [223,224], even when taking the role of some "minor components" into consideration. The compounds found in OLEX, when consumed in crude form, are able to maintain their biological activity. In the unsaponifiable fraction of olive oil, there are more than 200 "minor components". These minor components represent about $2 \%$ of the total weight and include a number of heterogeneous compounds that are chemically unrelated to fatty acids $[225,226]$. Recently, the nutraceutical properties of OLEX compounds and the antioxidant activity provided by these compounds have been the focus of a great amount of attention. In OLEX, the most abundant antioxidants are lipophilic and hydrophilic phenols [227], which are normally synthesised by the plant to react to various insect injuries and/or pathogen attacks [228,229].

Nutraceutical properties have mainly been attributed to secoiridoid oleuropein (OL) and its derivatives; the main alcohol 3, 4-dihydroxyphenyl ethanol, also known as hydroxytyrosol (HT); and p-hydroxyphenyl ethanol or tyrosol $[48,230]$. These compounds are released during the extraction process from the olive drupes into OLEX. In particular, OL is abundant in unprocessed olive leaves and drupes, while a higher concentration of HT may be found in the drupes and in olive oil, due to chemical and enzymatic reactions that occur in the plant during maturation of the fruit $[49,50]$. In addition, many agronomic factors may influence the final concentration in OLEX, such as the geographic origin of olive drupes, cultivar, olive tree irrigation, and ripening stage, as well as the various oil extraction conditions during crushing, malaxation, and OLEX separation [50].

The in vivo antioxidant activity of OL and HT is related to their high levels of bioavailability [51,52]. Various studies have documented a high degree of absorption of both compounds, which is fundamental to exerting their metabolic and pharmacokinetic properties [48]. OL and HT behave as antioxidants acting as anti-oxygen radicals, free radical scavengers, radical chain-breakers, and metal chelators. They can break peroxidative chain reactions and scavenge the peroxyl radicals with their catecholic structure, producing stable structures [53]. In vitro studies have shown a decrease in ROS production 
after treatment with OL or HT, suggesting a chelating action on such metal derived from copper-ion-induced oxidised low-density lipoprotein (oxLDL) [54]. Furthermore, in rats treated with doxorubicin (DOXO), it has been observed that OL could prevent cardiomyopathy [55]. In addition, Granados et al. have reported that in rats with breast cancer, HT attenuated DOXO-associated chronic cardiac toxicity, thus ameliorating mitochondrial dysfunction [56]. In particular, HT treatment significantly prevents mitochondrial swelling and vacuolization, improving the integrity of complex-III of the Mitochondrial Electron Transport Chain (METC) after DOXO treatment [56] (Figure 1). Treatment with OL also reduced the infarct size in normal and hypercholesterolemic rabbits [57]. Additionally, OL protection was associated with a reduction in total cholesterol and triglyceride levels in reperfused myocardium [57]. Furthermore, HT reduced the protein expression related to ageing, the infarct size, and apoptosis in cardiomyocytes [58]. In tyrosol-treated rats compared to non-treated animals, a reduced infarct size was observed, with a concomitant improvement in the myocardial function [59]. In particular, OL was able to inhibit the myocardial infarction size and reduce the levels of Creatine-Kinase MB isohenzyme (CK-MB) and lactate dehydrogenase $(\mathrm{LDH})$ in a model of myocardial ischemia-reperfusion in rats. The mechanism of olea derivatives is still unknown. However, recent data showed that, in myocardial I/R rats, OL modulated the ERK pathway and suppressed the induction of p53, p-MEK, and p-ERK protein expression [60]. Cisplatin-induced acute renal injury was attenuated by OL through the inhibition of p53 and ERK signalling in mice [61]. Moreover, evidence exists that the cardioprotective effects of OLEX and HT are mainly exerted via endoplasmic reticulum (ER) stress prevention [62]. Indeed, the administration of HT prevents ER-stress-induced apoptosis by inhibiting the mRNA and protein expression of GRP78 and CHOP in hypoxia-induced H9c2 cells. On the other hand, pre-treatment with OLEX prevents inflammation and reduces the infarct size, improving ejection fraction and shortening fraction FS in isoproterenol-induced myocardial infarction in rats [62]. Finally, recent data suggested that OL prevents oxidative stress directly scavenging $\mathrm{O}_{2}^{-}$in AngII-mediated human vascular progenitor cell (VPC) depletion. Furthermore, evidence has been collected suggesting that OL exerts its protective effects via upregulation of the ERK1/2-Prdx1 and 2 and Akt/eNOS signalling pathway [63] (Figure 2). Therefore, derivatives of Olea Europea L. appear to represent natural compounds able to exert a cardioprotective response acting on pathways which lead to the impairment of cardiomyocytes.

\subsection{Apple-Derived Natural SGLT 2 -Inhibitors}

The principle phenolic-glucoside in apple trees is phlorizin, which is present in roots, bark, shoots, and leaves [231]. It is a naturally competitive inhibitor of SGLT2, providing the first insights into the potential efficacy of this compound [64]. Many effects of the phlorizin-rich extract contribute to its potential use in treatments to ameliorate diabetes and other metabolic disorders. In fact, it has been reported that apple juice and apple extracts contain a total phenolic concentration of $11 \%-36 \%$ phlorizin, which could inhibit oxLDL levels [65]. Additionally, in isolated coronary artery rings, the aglycon of phlorizinphloretin-produces endothelium-independent relaxation [66,67].

Many pre-clinical studies have found that phlorizin produces effects such as lowering serum glucose and improving insulin-resistance [68-70]. In addition, with the scope of observing the absorption of delayed intestinal glucose, in 1997, Japanese researchers demonstrated an effect on the post-prandial rise of serum glucose after orally administering phlorizin to mice [71]. Following these observations, investigators at Tanabe Seiyaku Co., a Japanese pharmaceutical company, developed a phlorizin derivative; 3-(Benzo[b]furan-5yl)-2 ${ }^{\prime}, 6^{\prime}$-dihydroxy-4'-methyl-propiophenone-2'-O-(6-O-methoxycarbonyl)- $\beta$-D- glucopyranoside (T-1095) [72]. In particular, it was demonstrated that the oral administration of T1095 leads to an improvement in hyperglycaemia and insulin resistance in the skeletal muscle of streptozotocin (STZ)-induced diabetic rats [72]. In addition, data have also been provided showing that T-1095 improves hyperglycaemia by suppressing the renal reabsorption of glucose, possibly via inhibition of the expression of $\mathrm{Na}+-$ glucose cotransporters (SGLTs) 
and of the abnormal expression of GLUT2 in the kidney [73]. Therefore, due to the emerging evidence on the successful use of SGLT2 inhibitors in diabetic cardiomyopathy (see Section 2.5), it is likely that the phlorizin-rich apple extract may represent a potential candidate for supplementation in diabetes-associated impairment of the cardiac performance.

\subsection{Grape Seed Extract}

The grape seed extract (GSE) represents a source of active ingredients which have been suggested to have beneficial effects on many disease states, including cardiovascular disorders; for a review, see [232]. Among the active ingredients found in GSE, proanthocyanidins (PCs) were found to be able to produce therapeutic, biological, pharmacological and chemoprotective properties against free radicals and oxidative stress see [232]. Interestingly, grape seed PCs have shown cardioprotective effects through the modulation of mitochondrial and lysosomal function [74]. In fact, in isoproterenol- treated rats, cotreatment with PCs reduced the activities of lysosomal enzymes in the heart tissues and increased respiratory chain enzymes and mitochondrial activity [74].

Many of the cardiovascular benefits attributed to GSE rich in PCs have been found to be related to their antioxidant profile. Indeed, GSE exhibited dramatic concentrationdependent antioxidant activity [75]. Additionally, in mice, the dose-dependent protective ability of GSE was excellent against 12-O-tetradecanoylphorbol-13-acetate (TPA)-induced hepatic peroxidation, as well as DNA fragmentation, peritoneal macrophage activation, and brain lipid peroxidation [76]. Moreover, in a primary culture of human oral keratinocytes, GSPE demonstrated significant protection against DNA damage, oxidative stress induced by smokeless tobacco, and apoptotic cell death [77]. Additionally, GSE was shown to enhance the cytotoxic effects of idarubicin and 4-hydroxyperoxycyclophosphamide on Chang liver cells [78] and exerted a direct cytotoxic effect on cultured human cancer cells [79]. Finally, Bagchi [80] and Ray [81] reported that GSE also leads to significant protection against chemotherapeutic drug-induced cytotoxicity in common liver cells via the counteraction of both programmed and non-programmed cell death.

This was confirmed in cardiomyocytes [82]. Indeed, Sato et al. showed that GSE rich in PCs reduced the apoptotic cell death of cardiomyocytes in ischemia/reperfusion-induced damage, representing an effect driven by the activation of jnk-1 and c-jun [82]. Therefore, GSE rich in PCs leads to an antioxidant and anti-apoptotic effect in failing myocardial cells by means of antagonistic properties on ischaemia-reperfusion-induced activation of c-jun and by modulating the pro-apoptotic gene JNK-1.

\section{Conclusions and Future Perspectives}

The use of nutritional support and nutraceutical supplementation in HF patients has been suggested, over the last decades, on the basis of both pre-clinical and clinical studies carried out worldwide. However, there are consistent controversies with regards to defining the real contribution of nutraceutical interventions in the course of the disease and their correct impact on approaching hospitalisation and death in patients undergoing HF. Recent studies exploring pathophysiological mechanisms characterizing the early stages of $\mathrm{HF}$, mostly in the course of cardiometabolic disorders underlying impaired myocardial dysfunction, have allowed the possible identification of a condition of "cardiomyocyte frailty" in which oxidative stress and mitochondrial dysfunction seem to play a crucial role. Under these conditions, protective mechanisms which include autophagic responses and endogenous anti-oxidant enzyme overexpression are activated to antagonise the apoptotic cell death of myocardial cells. This stage of the disease is accompanied by an alteration in ER, calcium imbalance and an inappropriate regulation of MMPs, which have been shown to increase the stiffness of the left ventricle, leading to diastolic dysfunction. At this stage of the disease, based on their antioxidant and anti-apoptotic properties, several plant extracts, characterised by the specific modulation of oxidative processes which should occur at the early stages of cardiac dysfunction, are expected to play a role in counteracting the development of HF. To this end, contribution to the mobilisation of 
stem cells could have a further beneficial effect in supporting the failing myocardium at any stage of the disease. On the basis of this preliminary evidence, it is likely that a due combination of plant extracts, well-characterised in terms of active ingredients, may represent a potential resource to support endogenous compensatory mechanisms which characterise the "frail myocardium" at the early stages in the development of HF. This should be defined by means of multicentric clinical studies, randomised, double-blind and placebo-controlled, to be carried out on a large number of subjects, in order to verify the efficacy and safety profile of nutraceuticals. An assessment of their placement in therapy according to the stages of the disease is also required to define their contribution to disease progression, alongside conventional treatment assessed according to the international guidelines. Finally, a regulatory intervention to better define the right management of nutraceuticals in cardiovascular disease should increase their impact and credibility in clinical practice.

Author Contributions: V.M. (Vincenzo Mollace), M.M., and M.V. conceptualized and designed the review. V.M. (Vincenzo Mollace), R.M. (Rocco Mollace), A.T., M.G., V.M. (Vincenzo Musolino), C.C., J.M., R.M. (Roberta Macrì) and F.B., wrote the manuscript. G.M.C.R., S.D.A., A.J.S.C., P.S., M.C. and F.R. participated in drafting the article and revising it critically. All authors have read and agreed to the published version of the manuscript.

Funding: This study was supported by Programma Operativo Nazionale, PON-MIUR 03PE000_78_1 and 03PE000_78_2-Nutramed.

Data Availability Statement: Data available in a publicly accessible repository.

Acknowledgments: We would like to thank Yavette Schupe for the editorial support in revising the manuscript.

Conflicts of Interest: The authors declare no conflict of interest.

\section{References}

1. Ponikowski, P.; Anker, S.D.; AlHabib, K.F.; Cowie, M.R.; Force, T.L.; Hu, S.; Jaarsma, T.; Krum, H.; Rastogi, V.; Rohde, L.E.; et al. Heart failure: Preventing disease and death worldwide. ESC Heart Fail 2014, 1, 4-25. [CrossRef] [PubMed]

2. Gomez-Soto, F.M.; Andrey, J.L.; Garcia-Egido, A.A.; Escobar, M.A.; Romero, S.P.; Garcia-Arjona, R.; Gutierrez, J.; Gomez, F. Incidence and mortality of heart failure: A community-based study. Int. J. Cardiol. 2011, 151, 40-45. [CrossRef] [PubMed]

3. Kasznicki, J.; Drzewosk, J. Heart failure in the diabetic population-Pathophysiology, diagnosis and management. Med. Sci. 2014, 10, 546-556.

4. Nieminen, M.S.; Brutsaert, D.; Dickstein, K.; Drexler, H.; Follath, F.; Harjola, V.P.; Hochadel, M.; Komajda, M.; Lassus, J.; Lopez-Sendon, J.L.; et al. EuroHeart Failure Survey II (EHFS II): A survey on hospitalized acute heart failure patients: Description of population. Eur. Heart J. 2006, 27, 2725-2736. [CrossRef] [PubMed]

5. Kurmani, S.; Squire, I. Acute Heart Failure: Definition, Classification and Epidemiology. Curr. Heart Fail. Rep. 2017, 14, 385-392. [CrossRef]

6. Alissa, E.M.; Ferns, G.A. Functional foods and nutraceuticals in the primary prevention of cardiovascular diseases. J. Nutr. Metab. 2012, 2012, 569486. [CrossRef]

7. Gliozzi, M.; Walker, R.; Mollace, V. Bergamot polyphenols: Pleiotropic players in the treatment of metabolic syndrome. J. Metabolic Synd. 2014, 2, 35-42.

8. Tresserra-Rimbau, A.; Rimm, E.B.; Medina-Remón, A.; Martínez-González, M.A.; de la Torre, R.; Corella, D.; Salas-Salvadó, J.; Gómez-Gracia, E.; Lapetra, J.; Arós, F.; et al. Inverse association between habitual polyphenol intake and incidence of cardiovascular events in the PREDIMED study. Nutr. Metab. Cardiovasc. Dis. 2014, 24, 639-647. [CrossRef]

9. Mollace, V.; Gliozzi, M.; Carresi, C.; Musolino, V.; Oppedisano, F. Re-assessing the mechanism of action of n-3 PUFAs. Int. J. Cardiol. 2013, 170, S8-S11. [CrossRef]

10. Carresi, C.; Gliozzi, M.; Giancotta, C.; Scarcella, A.; Scarano, F.; Bosco, F.; Mollace, R.; Tavernese, A.; Vitale, C.; Musolino, V. Studies on the protective role of Bergamot polyphenols in doxorubicin-induced cardiotoxicity. PharmaNutrition 2016, 4, S19-S26. [CrossRef]

11. Sciatti, E.; Lombardi, C.; Ravera, A.; Vizzardi, E.; Bonadei, I.; Carubelli Gorga, V.E.; Metra, M. Nutritional deficiency in patients with heart failure. Nutrients 2016, 8, 442. [CrossRef] [PubMed]

12. Witte, K.K.; Clark, A.L.; Cleland, J.G. Chronic heart failure and micronutrients. J. Am. Coll. Cardiol. 2001, 37, 1765-1774. [CrossRef]

13. Pinho, C.P.S.; da Silveira, A.C. Nutritional aspects in heart failure. J. Nutr. Health Sci. 2014, 1, 305. 
14. Witte, K.K.; Nikitin, N.P.; Parker, A.C.; von Haehling, S.; Volk, H.D.; Anker, S.D.; Clark, A.L.; Cleland, J.G. The effect of micronutrient supplementation on quality-of-life and left ventricular function in elderly patients with chronic heart failure. Eur. Heart J. 2005, 26, 2238-2244. [CrossRef] [PubMed]

15. Cvetinovic, N.; Loncar, G.; Isakovic, A.M.; von Haehling, S.; Doehner, W.; Lainscak, M.; Farkas, J. Micronutrient depletion in heart failure: Common, clinically relevant and treatable. Int. J. Mol. Sci. 2019, 20, 5627. [CrossRef] [PubMed]

16. Witte, K.K.; Clark, A.L. Micronutrients and their supplementation in chronic cardiac failure. An update beyond theoretical perspectives. Heart Fail. Rev. 2006, 11, 65-74. [CrossRef]

17. Shimon, I.; Almog, S.; Vered, Z.; Seligmann, H.; Shefi, M.; Peleg, E.; Rosenthal, T.; Motro, M.; Halkin, H.; Ezra, D. Improved left ventricular function after thiamine supplementation in patients with congestive heart failure receiving long-term furosemide therapy. Am. J. Med. 1995, 98, 485-490. [CrossRef]

18. Deichmann, R.; Lavie, C.; Andrews, S. Coenzyme Q10 and statin-induced mitochondrial dysfunction. Ochsner J. 2010, 10, 16-21.

19. Sharma, A.; Fonarow, G.C.; Butler, J.; Ezekowitz, J.A.; Felker, G.M. Coenzyme Q10 and heart failure: A state-of-the-art review. Circ. Heart Fail. 2016, 9, e002639. [CrossRef]

20. Tsai, K.L.; Huang, Y.H.; Kao, C.L.; Yang, D.M.; Lee, H.C.; Chou, H.Y.; Chen, H.C.; Chiou, G.Y.; Chen, L.H.; Yang, Y.P.; et al. A novel mechanism of coenzyme Q10 protects against human endothelial cells from oxidative stress-induced injury by modulating NO-related pathways. J. Nutr. Biochem. 2012, 23, 458-468. [CrossRef]

21. Fotino, D.; Thompson-Paul, A.M.; Bazzano, L.A. Effect of coenzyme Q10 supplementation on heart failure: A meta-analysis. Am. J. Clin. Nutr. 2013, 97, 268-275. [CrossRef] [PubMed]

22. Mortensen, S.A.; Rosenfeldt, F.; Kumar, A.; Dolliner, P.; Filipiak, K.J.; Pella, D.; Alehagen, U.; Steurer, G.; Littarru, G.P. Q-SYMBIO Study Investigators. The effect of coenzyme Q10 on morbidity and mortality in chronic heart failure: Results from Q-SYMBIO: A randomized double-blind trial. JACC Heart Fail. 2014, 2, 641-649. [CrossRef] [PubMed]

23. Mollace, V.; Sacco, I.; Janda, E.; Malara, C.; Ventrice, D.; Colica, C.; Visalli, V.; Muscoli, S.; Ragusa, S.; Muscoli, C.; et al. Hypolipemic and hypoglycaemic activity of bergamot polyphenols: From animal models to human studies. Fitoterapia 2011, 82, 309-316. [CrossRef] [PubMed]

24. Mollace, V.; Scicchitano, M.; Paone, S.; Casale, F.; Calandruccio, C.; Gliozzi, M.; Musolino, V.; Carresi, C.; Maiuolo, J.; Nucera, S.; et al. Hypoglycemic and Hypolipemic Effects of a new lecithin formulation of bergamot Polyphenolic Fraction: A double blind, randomized, placebo-controlled study. Endocr. Metab. Immune Disord. Drug Targets 2019, 19, 136-143. [CrossRef] [PubMed]

25. Gliozzi, M.; Walker, R.; Muscoli, S.; Vitale, C.; Gratteri, S.; Carresi, C.; Musolino, V.; Russo, V.; Janda, E.; Ragusa, S.; et al. Bergamot polyphenolic fraction enhances rosuvastatin-induced effect on LDL-cholesterol, LOX-1 expression and protein kinase B phosphorylation in patients with hyperlipidemia. Int. J. Cardiol. 2013, 170, 140-145. [CrossRef] [PubMed]

26. Perrinjaquet-Moccetti, T.; Busjahn, A.; Schmidlin, C.; Schmidt, A.; Bradl, B.; Aydogan, C. Food supplementation with an olive (Olea europaea L.) leaf extract reduces blood pressure in borderline hypertensive monozygotic twins. Phytother. Res. 2008, 22, 1239-1242. [CrossRef]

27. Susalit, E.; Agus, N.; Effendi, I.; Tjandrawinata, R.R.; Nofiarny, D.; Perrinjaquet-Moccetti, T.; Verbruggen, M. Olive (Olea europaea) leaf extract effective in patients with stage-1 hypertension: Comparison with Captopril. Phytomedicine 2011, 18, 251-258. [CrossRef]

28. Zinman, B.; Wanner, C.; Lachin, J.M.; Fitchett, D.; Bluhmki, E.; Hantel, S.; Mattheus, M.; Devins, T.; Johansen, O.E.; Woerle, H.J.; et al. Empagliflozin, cardiovascular outcomes, and mortality in Type 2 Diabetes. N. Engl. J. Med. 2015, 373, 2117. [CrossRef]

29. Wiviott, S.D.; Raz, I.; Bonaca, M.P.; Mosenzon, O.; Kato, E.T.; Cahn, A.; Silverman, M.G.; Zelniker, T.A.; Kuder, J.F.; Murphy, S.A.; et al. Dapagliflozin and cardiovascular outcomes in Type 2 Diabetes. N. Engl. J. Med. 2019, 380, 347. [CrossRef]

30. Sarewicz, M.; Osyczka, A. electronic connection between the quinone and cytochrome c redox pools and its role in regulation of mitochondrial electron transport and redox signalling. Physiol. Rev. 2015, 95, 219-243. [CrossRef]

31. Tsai, H.Y.; Lin, C.P.; Huang, P.H.; Li, S.Y.; Chen, J.S.; Lin, F.Y.; Chen, J.W.; Lin, S.J. Coenzyme Q10 attenuates high glucose-induced endothelial progenitor cell dysfunction through AMP-Activated protein kinase pathways. J. Diabetes Res. 2016, $2016,6384759$. [CrossRef] [PubMed]

32. Mancuso, M.; Orsucci, D.; Volpi, L.; Calsolaro, V.; Siciliano, G. Coenzyme Q10 in neuromuscular and neurodegenerative disorders. Curr. Drug Targets 2010, 11, 111-121. [CrossRef] [PubMed]

33. Garjani, A.; Andalib, S.; Biabani, S.; Soraya, H.; Doustar, Y.; Garjani, A.; Maleki-Dizaji, N. Combined atorvastatin and coenzyme Q10 improve the left ventricular function in isoproterenol-induced heart failure in rat. Eur. J. Pharmacol. 2011, 666, 135-141. [CrossRef] [PubMed]

34. Zozina, V.I.; Covantev, S.; Goroshko, O.A.; Krasnykh, L.M.; Kukes, V.G. Coenzyme Q10 in cardiovascular and metabolic diseases: Current state of the problem. Curr. Cardiol. Rev. 2018, 14, 164-174. [CrossRef] [PubMed]

35. Niklowitz, P.; Onur, S.; Fischer, A.; Laudes, M.; Palussen, M.; Menke, T.; Döring, F. Coenzyme Q10 serum concentration and redox status in European adults: Influence of age, sex, and lipoprotein concentration. J. Clin. Biochem. Nutr. 2016, 58, 240-245. [CrossRef] [PubMed]

36. Molyneux, S.L.; Florkowski, C.M.; George, P.M.; Pilbrow, A.P.; Frampton, C.M.; Lever, M.; Richards, M. Coenzyme Q(10) an independent predictor of mortality in chronic heart failure. J. Am. Coll. Cardiol. 2008, 52, 1435-1441. [CrossRef] [PubMed]

37. Kjekshus, J.; Apetrei, E.; Barrios, V.; Böhm, M.; Cleland, J.G.F.; Cornel, J.H.; Dunselman, P.; Fonseca, C.; Goudev, A.; Grande, P.; et al. Rosuvastatin in older patients with systolic heart failure. Int. J. Clin. Pract. 2008, 62, 1. [CrossRef] [PubMed] 
38. Molyneux, S.L.; Young, J.M.; Florkowski, C.M.; Lever, M.; George, P.M. Coenzyme Q10: Is There a clinical role and a case for measurement? Clin. Biochem. Rev. 2008, 29, 71-82.

39. Carresi, C.; Gliozzi, M.; Musolino, V.; Scicchitano, M.; Scarano, F.; Bosco, F.; Nucera, S.; Maiuolo, J.; Macrì, R.; Ruga, S.; et al. The effect of natural antioxidants in the development of metabolic syndrome: Focus on bergamot polyphenolic fraction. Nutrients 2020, 12, 1504. [CrossRef]

40. Musolino, V.; Gliozzi, M.; Nucera, S.; Carresi, C.; Maiuolo, J.; Mollace, R.; Paone, S.; Bosco, F.; Scarano, F.; Scicchitano, M.; et al. The effect of bergamot polyphenolic fraction on lipid transfer protein system and vascular oxidative stress in a rat model of hyperlipemia. Lipids Health Dis. 2019, 18, 115. [CrossRef]

41. Musolino, V.; Gliozzi, M.; Scarano, F.; Bosco, F.; Scicchitano, M.; Nucera, S.; Carresi, C.; Ruga, S.; Zito, M.C.; Maiuolo, J.; et al. Bergamot polyphenols improve dyslipidemia and pathophysiological features in a mouse model of Non-Alcoholic Fatty Liver Disease. Sci. Rep. 2020, 10, 2565. [CrossRef] [PubMed]

42. Parafati, M.; Lascala, A.; Morittu, V.M.; Trimboli, F.; Rizzuto, A.; Brunelli, E.; Coscarelli, F.; Costa, N.; Britti, D.; Ehrlich, J.; et al. Bergamot polyphenol fraction prevents nonalcoholic fatty liver disease via stimulation of lipophagy in cafeteria diet-induced rat model of metabolic syndrome. Nutr. Biochem. 2015, 26, 938-948. [CrossRef] [PubMed]

43. Miceli, N.; Mondello, M.R.; Monforte, M.T.; Sdrafkakis, V.; Dugo, P.; Crupi, M.L.; Taviano, M.F.; De Pasquale, R.; Trovato, A. Hypolipidemic effects of Citrus bergamia Risso et Poiteau juice in rats fed a hypercholesterolemic diet. J. Agric. Food Chem. 2007, 55, 10671-10677. [CrossRef] [PubMed]

44. Musolino, V.; Gliozzi, M.; Carresi, C.; Maiuolo, J.; Mollace, R.; Bosco, F.; Scarano, F.; Scicchitano, M.; Maretta, A.; Palma, E.; et al. Lipid-lowering effect of bergamot polyphenolic fraction: Role of pancreatic cholesterol ester hydrolase. J. Biol. Regul. Homeost. Agents 2017, 31, 1087-1093. [PubMed]

45. Di Donna, L.; De Luca, G.; Mazzotti, F.; Napoli, A.; Salerno, R.; Taverna, D.; Sindona, G. Statin-like principles of bergamot fruit (Citrus bergamia): Isolation of 3-hydroxymethylglutaryl flavonoid glycosides. J. Nat. Prod. 2009, 72, 1352-1354. [CrossRef]

46. Leopoldini, M.; Malaj, N.; Toscano, M.; Sindona, G.; Russo, N. On the inhibitor effects of bergamot juice flavonoids binding to the 3-hydroxy-3-methylglutaryl-CoA reductase (HMGR) enzyme. J. Agric. Food Chem. 2010, 58, 10768-10773. [CrossRef]

47. Di Donna, L.; Iacopetta, D.; Cappello, A.R.; Gallucci, G.; Martello, E.; Fiorillo, M.; Dolce, V.; Sindona, G. Hypocholesterolaemic activity of 3-hydroxy-3-methyl-glutaryl flavanones enriched fraction from bergamot fruit (Citrus bergamia): 'In vivo' studies. J. Funct. Foods 2014, 7, 558-568. [CrossRef]

48. De Bock, M.; Thorstensen, E.B.; Derraik, J.G.; Henderson, H.V.; Hofman, P.L.; Cutfield, W.S. Human absorption and metabolism of oleuropein and hydroxytyrosol ingested as olive (Olea europaea L.) leaf extract. Mol. Nutr. Food Res. 2013, 57, $2079-2085$. [CrossRef]

49. Kouka, P.; Tsakiri, G.; Tzortzi, D.; Dimopoulou, S.; Sarikaki, G.; Stathopoulos, P.; Veskoukis, A.S.; Halabalaki, M.; Skaltsounis, A.L.; Kouretas, D. The polyphenolic composition of extracts derived from different greek extra virgin olive oils is correlated with their antioxidant potency. Oxid. Med. Cell. Longev. 2019, 2019, 1870965. [CrossRef]

50. Talhaoui, N.; Gómez-Caravaca, A.M.; León, L.; De la Rosa, R.; Fernández-Gutiérrez, A.; Segura-Carretero, A. From olive fruits to olive oil: Phenolic compound transfer in six different olive cultivars grown under the same agronomical conditions. Int. J. Mol. Sci. 2016, 17, 337. [CrossRef]

51. Gorzynik-Debicka, M.; Przychodzen, P.; Cappello, F.; Kuban-Jankowska, A.; Marino Gammazza, A.; Knap, N.; Wozniak, M.; Gorska-Ponikowska, M. Potential health benefits of olive oil and plant polyphenols. Int. J. Mol. Sci. 2018, 19, 686. [CrossRef] [PubMed]

52. Žugčić, T.; Abdelkebir, R.; Alcantara, C.; Collado, M.C.; García-Pérez, J.V.; Meléndez-Martínez, A.J.; Režek Jambrak, A.; Lorenzo, J.M.; Barba, F.J. From extraction of valuable compounds to health promoting benefits of olive leaves through bioaccessibility, bioavailability and impact on gut microbiota. Trends Food Sci. Technol. 2019, 83, 63-77. [CrossRef]

53. Bulotta, S.; Oliverio, M.; Russo, D.; Procopio, A. Biological Activity of Oleuropein and its Derivatives. In Natural Products; Springer: Heidelberg, Germany, 2013; Volume 156, pp. 3605-3638.

54. Andrikopoulos, N.K.; Kaliora, A.C.; Assimopoulou, A.N.; Papageorgiou, V.P. Inhibitory activity of minor polyphenolic and nonpolyphenolic constituents of olive oil against in vitro low-density lipoprotein oxidation. J. Med. Food 2002, 5, 1-7. [CrossRef] [PubMed]

55. Andreadou, I.; Mikros, E.; Ioannidis, K.; Sigala, F.; Naka, K.; Kostidis, S.; Farmakis, D.; Tenta, R.; Kavantzas, N.; Bibli, S.I.; et al. Oleuropein prevents doxorubicin-induced cardiomyopathy interfering with signaling molecules and cardiomyocyte metabolism. J. Mol. Cell. Cardiol. 2014, 69, 4-16. [CrossRef] [PubMed]

56. Granados-Principal, S.; El-azem, N.; Pamplona, R.; Ramirez-Tortosa, C.; Pulido-Moran, M.; Vera-Ramirez, L.; Quiles, J.L.; Sanchez-Rovira, P.; Naudí, A.; Portero-Otin, M.; et al. Hydroxytyrosol ameliorates oxidative stress and mitochondrial dysfunction in doxorubicin-induced cardiotoxicity in rats with breast cancer. Biochem. Pharmacol. 2014, 90, 25-33. [CrossRef]

57. Andreadou, I.; Iliodromitis, E.K.; Mikros, E.; Constantinou, M.; Agalias, A.; Magiatis, P.; Skaltsounis, A.L.; Kamber, E.; TsantiliKakoulidou, A.; Kremastinos, D.T. The olive constituent oleuropein exhibits anti-ischemic, antioxidative, and hypolipidemic effects in anesthetized rabbits. J. Nutr. 2006, 136, 2213-2219. [CrossRef]

58. Mattera, R.; Benvenuto, M.; Giganti, M.G.; Tresoldi, I.; Pluchinotta, F.R.; Bergante, S.; Tettamanti, G.; Masuelli, L.; Manzari, V.; Modesti, A.; et al. Effects of Polyphenols on Oxidative Stress-Mediated Injury in Cardiomyocytes. Nutrients 2017, 9, 523. [CrossRef] 
59. Samuel, S.M.; Thirunavukkarasu, M.; Penumathsa, S.V.; Paul, D.; Maulik, N. Akt/FOXO3a/SIRT1-mediated cardioprotection by n-tyrosol against ischemic stress in rat in vivo model of myocardial infarction: Switching gears toward survival and longevity. J. Agric. Food Chem. 2008, 56, 9692-9698. [CrossRef]

60. Jin, H.X.; Zhang, Y.H.; Guo, R.N.; Zhao, S.N. Inhibition of MEK/ERK/STAT3 signaling in oleuropein treatment inhibits myocardial ischemia/reperfusion. Int. J. Mol. Med. 2018, 2, 1034-1043. [CrossRef]

61. Potočnjak, I.; Škoda, M.; Pernjak-Pugel, E.; Pavletić Peršić, M.; Domitrović, R. Oral administration of oleuropein attenuates cisplatin-induced acute renal injury in mice through inhibition of ERK signaling. Mol. Nutr. Food Res. 2016, 60, 530-541. [CrossRef]

62. Wu, L.X.; Xu, Y.Y.; Yang, Z.J.; Feng, Q. Hydroxytyrosol and olive leaf extract exert cardioprotective effects by inhibiting GRP78 and CHOP expression. J. Biomed. Res. 2018, 32, 371-379. [PubMed]

63. Choi, S.Y.; Joo, B.H.; Lee, S.J.; Choi, H.Y.; Park, J.H.; Baek, S.H.; Kwon, S.M. Oleuropein prevents angiotensin II-mediated human vascular progenitor cell depletion. Int. J. Cardiol. 2015, 181, 160-165. [CrossRef] [PubMed]

64. Diedrich, D.F. Competitive inhibition of intestinal glucose transport by phlorizin analogs. Arch. Biochem. Biophys. 1966, 117, 248-256. [CrossRef]

65. Pearson, D.A.; Tan, C.H.; German, J.B.; Davis, P.A.; Gershwin, M.E. Apple juice inhibits human low density lipoprotein oxidation. Life Sci. 1999, 64, 1913-1920. [CrossRef]

66. Ehrenkranz, J.R.; Lewis, N.G.; Kahn, C.R.; Roth, J. Phlorizin: A review. Diabetes Metab. Res. Rev. 2005, 21, 31-38. [CrossRef]

67. Figtree, G.A.; Griffiths, H.; Lu, Y.Q.; Webb, C.M.; MacLeod, K.; Collins, P. Plant-derived estrogens relax coronary arteries in vitro by a calcium antagonistic mechanism. Am. Coll. Cardiol. 2000, 35, 1977-1985. [CrossRef]

68. Rossetti, L.; Smith, D.; Shculman, G.I.; Papachristou, D.; DeFronzo, R.A. Correction of hyperglycemia with phlorizin normalizes tissue sensitivity to insulin in diabetic rats. J. Clin. Investig. 1987, 79, 1510-1515. [CrossRef]

69. Blondel, O.; Bailbe, D.; Portha, B. Insulin resistance in rats with non-insulin-dependent diabetes induced by neonatal (5 days) streptozotocin: Evidence for reversal following phlorizin treatment. Metabolism 1990, 39, 787-793. [CrossRef]

70. Kahn, B.B.; Shulman, G.I.; DeFronzo, R.A.; Cushman, S.W.; Rossetti, L. Normalization of blood glucose in diabetic rats with phlorizin treatment reverses insulin-resistant glucose transport in adipose cells without restoring glucose transporter gene expression. J. Clin. Investig. 1991, 87, 561-570. [CrossRef]

71. Takii, H.; Matsumoto, K.; Kometani, T.; Okada, S.; Fushiki, T. Lowering effect of phenolic glycosides on the rise in postprandial glucose in mice. Biosci. Biotechnol. Biochem. 1997, 61, 1531-1535. [CrossRef]

72. Oku, A.; Ueta, K.; Arakawa, K.; Kano-Ishihara, T.; Matsumoto, T.; Adachi, T.; Yasuda, K.; Tsuda, K.; Ikezawa, K.; Saito, A. Correction of hyperglycemia and insulin sensitivity by T-1095, an inhibitor of renal $\mathrm{Na}^{+}$-glucose cotransporters, in streptozotocininduced diabetic rats. Jpn. J. Pharmacol. 2000, 84, 351-354. [CrossRef] [PubMed]

73. Adachi, T.; Yasuda, K.; Okamoto, Y.; Shihara, N.; Oku, A.; Ueta, K.; Kitamura, K.; Saito, A.; Iwakura, I.; Yamada, Y.; et al. T-1095, a renal $\mathrm{Na}+$-glucose transporter inhibitor, improves hyperglycemia in streptozotocin-induced diabetic rats. Metabolism 2000, 49, 990-995. [CrossRef] [PubMed]

74. Karthikeyan, K.; Sarala Bai, B.R.; Niranjali Devaraj, S. Grape seed proanthocyanidins ameliorates isoproterenol-induced myocardial injury in rats by stabilizing mitochondrial and lysosomal enzymes: An in vivo study. Life Sci. 2007, 81, 1615-1621. [CrossRef] [PubMed]

75. Du, Y.; Guo, H.; Lou, H. Grape seed polyphenols protect cardiac cells from apoptosis via induction of endogenous antioxidant enzymes. J. Agric. Food Chem. 2007, 55, 1695-1701. [CrossRef]

76. Bagchi, D.; Garg, A.; Krohn, R.L.; Bagchi, M.; Bagchi, D.J.; Balmoori, J.; Stohs, S.J. Protective effects of grape seed proanthocyanidins and selected antioxidants against TPA-induced hepatic and brain lipid peroxidation and DNA fragmentation, and peritoneal macrophage activation in mice. Gen. Pharmacol. 1998, 30, 771-776. [CrossRef]

77. Bagchi, M.; Kuszynski, C.A.; Balmoori, J.; Joshi, S.S.; Stohs, S.J.; Bagchi, D. Protective effects of antioxidants against smokeless tobacco-induced oxidative stress and modulation of Bcl-2 and p53 genes in human oral keratinocytes. Free Radic. Res. 2001, 35, 181-194. [CrossRef]

78. Joshi, S.S.; Kuszynski, C.A.; Benner, E.J.; Balmoori, J.C.A.; Bagchi, M.; Bagchi, D. Amelioration of cytotoxic effects of idarubicin and 4-hydroxyperoxycyclophosphamide on Chang liver cells by a novel grape seed proanthocyanidin extract. FASEB J. 1998, 12, A774.

79. Ye, X.; Krohn, R.L.; Liu, W.; Joshi, S.S.; Kuszynski, C.A.; McGinn, T.R.; Bagchi, M.; Preuss, H.G.; Stohs, S.J.; Bagchi, D. The cytotoxic effects of a novel IH636 grape seed proanthocyanidin extract on cultured human cancer cells. Mol. Cell. Biochem. 1999, 196, 99-108. [CrossRef]

80. Bagchi, D.; Ray, S.D.; Patel, D.; Bagchi, M. Protection against drug- and chemical-induced multiorgan toxicity by a novel grape seed proanthocyanidin extract. Drugs Exp. Clin. Res. 2001, 27, 3-15.

81. Ray, S.D.; Kumar, M.A.; Bagchi, D. A novel proanthocyanidin IH636 grape seed extract increases in vivo bcl-XL expression and prevents acetaminophen-induced programmed and unprogrammed cell death in mouse liver. Arch. Biochem. Biophys. 1999, 369, 42-58. [CrossRef]

82. Sato, M.; Bagchi, D.; Tosaki, A.; Das, D.K. Grape seed proanthocyanidin reduces cardiomyocyte apoptosis by inhibiting ischemia/reperfusion-induced activation of jnk-1 and c-jun. Free Radic. Biol. Med. 2001, 31, 729-737. [CrossRef]

83. Yuan, Z.; Du, W.; He, X.; Zhang, D.; He, W. Tribulus terrestris ameliorates oxidative stress-induced ARPE-19 cell injury through the PI3K/Akt-Nrf2 Signaling Pathway. Oxid. Med. Cell. Longev. 2020, 28, 7962393. 
84. Raj, P.; Louis, X.L.; Thandapilly, S.J.; Movahed, A.; Zieroth, S.; Netticadan, T. Potential of resveratrol in the treatment of heart failure. Life Sci. 2014, 95, 63-71. [CrossRef] [PubMed]

85. Dyck, G.J.B.; Raj, P.; Zieroth, S.; Dyck, J.R.B.; Ezekowitz, J.A. The effects of resveratrol in patients with cardiovascular disease and heart failure: A narrative review. Int. J. Mol. Sci. 2019, 20, 904. [CrossRef]

86. Lagouge, M.; Argmann, C.; Gerhart-Hines, Z.; Meziane, H.; Lerin, C.; Daussin, F.; Messadeq, N.; Milne, J.; Lambert, P.; Elliott, P.; et al. Resveratrol improves mitochondrial function and protects against metabolic disease by activating SIRT1 and PGC-1a. Cell 2006, 127, 1109-1122. [CrossRef]

87. Gu, X.S.; Wang, Z.B.; Ye, Z.; Lei, J.P.; Li, L.; Su, D.F.; Zheng, X. Resveratrol, an activator of SIRT1, upregulates AMPK and improves cardiac function in heart failure. Genet. Mol. Res. 2014, 13, 323-335. [CrossRef]

88. Kanamori, H.; Takemura, Y.G.; Goto, K.; Tsujimoto, A.; Ogino, A.; Takeyama, T.; Kawaguchi, T.; Watanabe, T.; Morishita, K.; Kawasaki, M.; et al. Cardiovascular, pulmonary and renal pathology resveratrol reverses remodelling in hearts with large, old myocardial infarctions through enhanced autophagy-activating AMP Kinase pathway. Am. J. Pathol. 2013, 182, 3. [CrossRef]

89. Marques, B.; Trindade, M.; Aquino, J.C.F.; Cunha, A.R.; Gismondi, R.O.; Neves, M.F.; Oigman, W. Beneficial effects of acute trans-resveratrol supplementation in treated hypertensive patients with endothelial dysfunction. Clin. Exp. Hypertens. 2018, 40, 218-223. [CrossRef]

90. Tome-Carneiro, J.; Gonzalvez, M.; Larrosa, M.; Yanez-Gascon, M.J.; Garcia-Almagro, F.J.; Ruiz-Ros, J.A.; Tomas-Barberan, F.A.; Garcia-Conesa, M.T.; Espin, J.C. Grape resveratrol increases serum adiponectin and downregulates inflammatory genes in peripheral blood mononuclear cells: A triple-blind, placebo-controlled, one-year clinical trial in patients with stable coronary artery disease. Cardiovasc. Drugs Ther. 2013, 27, 37-48. [CrossRef]

91. Tome-Carneiro, J.; Gonzalvez, M.; Larrosa, M.; Yanez-Gascon, M.J.; Garcia-Almagro, F.J.; Ruiz-Ros, J.A.; Garcia-Conesa, M.T.; Tomas-Barberan, F.A.; Espin, J.C. One-year consumption of a grape nutraceutical containing resveratrol improves the inflammatory and fibrinolytic status of patients in primary prevention of cardiovascular disease. Am. J. Cardiol. 2012, 110, 356-363. [CrossRef]

92. Bhatt, J.K.; Thomas, S.; Nanjan, M.J. Resveratrol supplementation improves glycemic control in type 2 diabetes mellitus. Nutr. Res. 2012, 32, 537-541. [CrossRef] [PubMed]

93. Magyar, K.; Halmosi, R.; Palfi, A.; Feher, G.; Czopf, L.; Fulop, A.; Battyany, I.; Sumegi, B.; Toth, K.; Szabados, E. Cardioprotection by resveratrol: A human clinical trial in patients with stable coronary artery disease. Clin. Hemorheol. Microcirc. 2012, 50, 179-187. [CrossRef] [PubMed]

94. Neubauer, S. The Failing Heart-An Engine Out of Fuel. N. Engl. J. Med. 2007, 356, 1140-1151. [CrossRef] [PubMed]

95. Bottomley, P.A. MR spectroscopy of the human heart: The status and the challenges. Radiology 1994, 191, 593-612. [CrossRef]

96. Ingwall, J.S.; Atkinson, D.E.; Clarke, K.; Fetters, J.K. Energetic correlates of cardiac failure: Changes in the creatine kinase system in the failing myocardium. Eur. Heart J. 1990, 11 (Suppl. B), 108-115. [CrossRef]

97. Starling, R.C.; Hammer, D.F.; Altschuld, R.A. Human myocardial ATP content and in vivo contractile function. Mol. Cell. Biochem. 1998, 180, 171-177. [CrossRef]

98. Zhou, B.; Tian, R. Mitochondrial dysfunction in pathophysiology of heart failure. J. Clin. Investig. 2018, 128, 3716-3726. [CrossRef]

99. Gorski, P.A.; Ceholski, D.K.; Hajjar, R.J. Altered myocardial calcium cycling and energetics in heart failure-A rational approach for disease treatment. Cell Metab. 2015, 21, 183-194. [CrossRef]

100. Montgomery, C.; Hamilton, N.; Ianuzzo, C.D. Energy status of the rapidly paced canine myocardium in congestive heart failure. J. Appl. Physiol. 1992, 73, 2363-2367. [CrossRef]

101. Doenst, T.; Pytel, G.; Schrepper, A.; Amorim, P.; Färber, G.; Shingu, Y.; Mohr, F.W.; Schwarzer, M. Decreased rates of substrate oxidation ex vivo predict the onset of heart failure and contractile dysfunction in rats with pressure overload. Cardiovasc. Res. 2010, 86, 461-470. [CrossRef]

102. Chidsey, C.A.; Weinbach, E.C.; Pool, P.E.; Morrow, A.G. Biochemical studies of energy production in the failing human heart. J. Clin. Investig. 1966, 45, 40-50. [CrossRef] [PubMed]

103. Sobel, B.E.; Spann, J.F.; Pool, P.E.; Sonnenblick, E.H.; Braunwald, E. Normal oxidative phosphorylation in mitochondria from the failing heart. Circ. Res. 1967, 21, 355-364. [CrossRef]

104. Cordero-Reyes, A.M.; Gupte, A.A.; Youker, K.A.; Loebe, M.; Hsueh, W.A.; Torre-Amione, G.; Taegtmeyer, H.; Hamilton, D.J. Freshly isolated mitochondria from failing human hearts exhibit preserved respiratory function. J. Mol. Cell. Cardiol. 2014, 68, 98-105. [CrossRef] [PubMed]

105. Holzem, K.M.; Vinnakota, K.C.; Ravikumar, V.K.; Madden, E.J.; Ewald, G.A.; Dikranian, K.; Beard, D.A.; Efimov, I.R. Mitochondrial structure and function are not different between non-failing donor and end-stage failing human hearts. FASEB J. 2016, 30, 2698-2707. [CrossRef]

106. Sharov, V.G.; Todor, A.V.; Silverman, N.; Goldstein, S.; Sabbah, H.N. Abnormal mitochondrial respiration in failed human myocardium. J. Mol. Cell. Cardiol. 2000, 32, 2361-2367. [CrossRef]

107. Nickel, A.; Loffler, J.; Maack, C. Myocardial energetics in heart failure. Basic Res. Cardiol. 2013, 108, 358. [CrossRef]

108. Razeghi, P.; Young, M.E.; Alcorn, J.L.; Moravec, C.S.; Frazier, O.H.; Taegtmeyer, H. Metabolic gene expression in fetal and failing human heart. Circulation 2001, 104, 2923-2931. [CrossRef] 
109. Chen, Y.; Csordas, G.; Jowdy, C.; Schneider, T.G.; Csordas, N.; Wang, W.; Liu, Y.; Kohlhaas, M.; Meiser, M.; Bergem, S.; et al. Mitofusin 2-containing mitochondrial-reticular microdomains direct rapid cardiomyocyte bioenergetic responses via interorganelle $\mathrm{Ca}^{2+}$ crosstalk. Circ. Res. 2012, 111, 863-875. [CrossRef]

110. Goh, K.Y.; Qu, J.; Hong, H.; Liu, T.; Dell'Italia, L.J.; Wu, Y.; O’Rourke, B.; Zhou, L. Impaired mitochondrial network excitability in failing guinea-pig cardiomyocytes. Cardiovasc. Res. 2016, 109, 79-89. [CrossRef]

111. Maack, C. Orphaned mitochondria in heart failure. Cardiovasc. Res. 2016, 109, 6-8. [CrossRef]

112. Yu, Z.; Chen, R.; Li, M.; Yu, Y.; Liang, Y.; Han, F.; Qin, S.; Chen, X.; Su, Y.; Ge, J. Mitochondrial calcium uniporter inhibition provides cardioprotection in pressure overload-induced heart failure through autophagy enhancement. Int. J. Cardiol. 2018, 271, 161-168. [CrossRef] [PubMed]

113. Tahrir, F.G.; Langford, D.; Amini, S.; Mohseni Ahooyi, T.; Khalili, K. Mitochondrial quality control in cardiac cells: Mechanisms and role in cardiac cell injury and disease. J. Cell. Physiol. 2019, 234, 8122-8133. [CrossRef] [PubMed]

114. Wang, K.; Xu, Y.; Sun, Q.; Long, J.; Liu, J.; Ding, J. Mitochondria regulate cardiac contraction through ATP-dependent and independent mechanisms. Free Radic. Res. 2018, 52, 1256-1265. [CrossRef] [PubMed]

115. Octavia, Y.; Brunner-La Rocca, H.P.; Moens, A.L. NADPH oxidase-dependent oxidative stress in the failing heart: From pathogenic roles to therapeutic approach. Free Radic. Biol. Med. 2012, 15, 291-297. [CrossRef]

116. Nickel, A.G.; von Hardenberg, A.; Hohl, M.; Löffler, J.R.; Kohlhaas, M.; Becker, J.; Reil, J.C.; Kazakov, A.; Bonnekoh, J.; Stadelmaier, M.; et al. Reversal of mitochondrial transhydrogenase causes oxidative stress in heart failure. Cell Metab. 2005, 22, 472-484. [CrossRef]

117. Aon, M.A.; Cortassa, S.; O’Rourke, B. Redox-optimized ROS balance: A unifying hypothesis. Biochim. Biophys. Acta 2010, 1797, 865-877. [CrossRef]

118. Huang, P.L. eNOS, metabolic syndrome and cardiovascular disease. Trends Endocrinol. Metab. 2009, 20, 295-302. [CrossRef]

119. Zorov, D.B.; Juhaszova, M.; Sollott, S.J. Mitochondrial reactive oxygen species (ROS) and ROS-induced ROS release. Physiol. Rev. 2014, 94, 909-950. [CrossRef]

120. Stehling, O.; Lill, R. The role of mitochondria in cellular iron-sulfur protein biogenesis: Mechanisms, connected processes, and diseases. Cold Spring Harb. Perspect. Biol. 2013, 5, a011312. [CrossRef]

121. Paradies, G.; Paradies, V.; Ruggiero, F.M.; Petrosillo, G. Oxidative stress, cardiolipin and mitochondrial dysfunction in nonalcoholic fatty liver disease. World J. Gastroenterol. 2014, 20, 14205-14218. [CrossRef]

122. Paradies, G.; Petrosillo, G.; Paradies, V.; Ruggiero, F.M. Role of cardiolipin peroxidation and $\mathrm{Ca}^{2+}$ in mitochondrial dysfunction and disease. Cell Calcium. 2009, 45, 643-650. [CrossRef] [PubMed]

123. Paradies, G.; Paradies, V.; De Benedictis, V.; Ruggiero, F.M.; Petrosillo, G. Functional role of cardiolipin in mitochondrial bioenergetics. Biochimica et Biophysica Acta (BBA) 2014, 1837, 408-417. [CrossRef] [PubMed]

124. Cheng, J.; Nanayakkara, G.; Shao, Y.; Cueto, R.; Wang, L.; Yang, W.Y.; Tian, Y.; Wang, H.; Yang, X. mitochondrial proton leak plays a critical role in pathogenesis of cardiovascular diseases. Adv. Exp. Med. Biol. 2017, 982, 359-370. [PubMed]

125. Karamanlidis, G.; Nascimben, L.; Couper, G.S.; Shekar, P.S.; del Monte, F.; Tian, R. Defective DNA replication impairs mitochondrial biogenesis in human failing hearts. Circ. Res. 2010, 106, 1541-1548. [CrossRef]

126. Ide, T.; Tsutsui, H.; Hayashidani, S.; Kang, D.; Suematsu, N.; Nakamura, K.; Utsumi, H.; Hamasaki, N.; Takeshita, A. Mitochondrial DNA damage and dysfunction associated with oxidative stress in failing hearts after myocardial infarction. Circ. Res. 2001, 88, 529-535. [CrossRef]

127. Dhalla, N.S.; Temsah, R.M.; Netticadan, T. Role of oxidative stress in cardiovascular diseases. J. Hypertens. 2000, 18, 655-673. [CrossRef]

128. Arrieta, A.; Blackwood, E.A.; Stauffer, W.T.; Glembotski, C.C. Integrating ER and Mitochondrial Proteostasis in the Healthy and Diseased Heart. Front. Cardiovasc. Med. 2020, 6, 193. [CrossRef]

129. Glembotski, C.C. Endoplasmic reticulum stress in the heart. Circ. Res. 2007, 101, 975-984. [CrossRef]

130. Jin, J.K.; Blackwood, E.A.; Azizi, K.; Thuerauf, D.J.; Fahem, A.G.; Hofmann, C.; Kaufman, R.J.; Doroudgar, S.; Glembotski, C.C. ATF6 decreases myocardial ischemia/reperfusion damage and links ER stress and oxidative stress signaling pathways in the heart. Circ. Res. 2017, 120, 862-875. [CrossRef]

131. Ochoa, C.D.; Wu, R.F.; Terada, L.S. ROS signaling and ER stress in cardiovascular disease. Mol. Asp. Med. 2018, 63, 18-29. [CrossRef]

132. Chen, C.-Y.; Zhang, S.-L.; Liu, Z.-Y.; Tian, Y.; Sun, Q. Cadmium toxicity induces ER stress and apoptosis via impairing energy homoeostasis in cardiomyocytes. Biosci. Rep. 2015, 35, e00214. [CrossRef] [PubMed]

133. Cao, S.S.; Kaufman, R.J. Endoplasmic Reticulum Stress and Oxidative Stress in Cell Fate Decision and Human Disease. Antioxid. Redox Signal. 2014, 21, 396-413. [CrossRef] [PubMed]

134. Martucciello, S.; Masullo, M.; Cerulli, A.; Piacente, S. Natural Products Targeting ER Stress, and the Functional Link to Mitochondria. Int. J. Mol. Sci. 2020, 21, 1905. [CrossRef] [PubMed]

135. Wang, S.; Binder, P.; Fang, Q.; Wang, Z.; Xiao, W.; Liu, W.; Wang, X. Endoplasmic reticulum stress in the heart: Insights into mechanisms and drug targets. Br. J. Pharmacol. 2018, 175, 1293-1304. [CrossRef] [PubMed]

136. Saito, A.; Ochiai, K.; Kondo, S.; Tsumagari, K.; Murakami, T.; Cavener, D.R.; Imaizumi, K. Endoplasmic reticulum stress response mediated by the PERK-eIF2(alpha)-ATF4 pathway is involved in osteoblast differentiation induced by BMP2. J. Biol. Chem. 2011, 286, 4809-4818. [CrossRef] [PubMed] 
137. Ni, M.; Zhang, Y.; Lee, A.S. Beyond the endoplasmic reticulum: Atypical GRP78 in cell viability, signalling and therapeutic targeting. Biochem. J. 2011, 434, 181-188. [CrossRef] [PubMed]

138. Ariyasinghe, N.R.; Lyra-Leite, D.M.; McCain, M.L. Engineering cardiac microphysiological systems to model pathological extracellular matrix remodeling. Am. J. Physiol. Heart Circ. Physiol. 2018, 315, H771-H789. [CrossRef]

139. Frangogiannis, N.G. The extracellular matrix in ischemic and nonischemic heart failure. Circ. Res. 2019, 125, 117-146. [CrossRef]

140. Takawale, A.; Sakamuri, S.S.; Kassiri, Z. Extracellular matrix communication and turnover in cardiac physiology and pathology. Compr. Physiol. 2015, 5, 687-719.

141. Kelly, D.; Cockerill, G.; Ng, L.L.; Thompson, M.; Khan, S.; Samani, N.J.; Squire, I.B. Plasma matrix metalloproteinase-9 and left ventricular remodelling after acute myocardial infarction in man: A prospective cohort study. Eur. Heart J. 2007, 28, 711-718 [CrossRef]

142. Hsiao, K.C.; Tsai, J.P.; Yang, S.F.; Lee, W.C.; Huang, J.Y.; Chang, S.C.; Hso, C.S.; Chang, H.R. MMP-2 serum concentrations predict mortality in hemodialysis patients: A 5-year cohort study. Clin. Chim. Acta 2016, 452, 161-166. [CrossRef] [PubMed]

143. Hemdahl, A.L.; Gabrielsen, A.; Zhu, C.; Eriksson, P.; Hedin, U.; Kastrup, J.; Thorén, P.; Hansson, G.K. Expression of neutrophil gelatinase-associated lipocalin in atherosclerosis and myocardial infarction. Arterioscler. Thromb. Vasc. Biol. 2006, 26, 136-142. [CrossRef] [PubMed]

144. Sawicki, G.; Leon, H.; Sawicka, J.; Sariahmetoglu, M.; Schulze, C.J.; Scott, P.G.; Szczesna-Cordary, D.; Schulz, R. Degradation of myosin light chain in isolated rat hearts subjected to ischemia-reperfusion injury: A new intracellular target for matrix metalloproteinase-2. Circulation 2005, 112, 544-552. [CrossRef] [PubMed]

145. Belo, V.A.; Guimarães, D.A.; Castro, M.M. Matrix metalloproteinase 2 as a potential mediator of vascular smooth muscle cell migration and chronic vascular remodelling in Hypertension. J. Vasc. Res. 2015, 52, 221-231. [CrossRef]

146. Papazafiropoulou, A.; Tentolouris, N. Matrix metalloproteinases and cardiovascular diseases. Hippokratia 2009, 13, 76-82.

147. Lalu, M.M.; Pasini, E.; Schulze, C.J.; Ferrari-Vivaldi, M.; Ferrari-Vivaldi, G.; Bachetti, T.; Schulz, R. Ischaemia-reperfusion injury activates matrix metalloproteinases in the human heart. Eur. Heart J. 2005, 26, 27-35. [CrossRef]

148. DeCoux, A.; Lindsey, M.L.; Villarreal, F.; Garcia, R.A.; Schulz, R. Myocardial matrix metalloproteinase-2: Inside out and upside down. J. Mol. Cell. Cardiol. 2014, 77, 64-72. [CrossRef]

149. Liu, P.; Sun, M.; Sader, S. Matrix metalloproteinases in cardiovascular disease. Can. J. Cardiol. 2006, 22 (Suppl. B), 25B-30B. [CrossRef]

150. Wang, G.Y.; Bergman, M.R.; Nguyen, A.P.; Turcato, S.; Swigart, P.M.; Rodrigo, M.C.; Simpson, P.C.; Karliner, J.S.; Lovett, D.H.; Baker, A.J. Cardiac transgenic matrix metalloproteinase-2 expression directly induces impaired contractility. Cardiovasc. Res. 2006, 69, 688-696. [CrossRef]

151. Azevedo, A.; Prado, A.F.; Antonio, R.C.; Issa, J.P.; Gerlach, R.F. Matrix metalloproteinases are involved in cardiovascular diseases. Basic Clin. Pharmacol. Toxicol. 2014, 115, 301-314. [CrossRef]

152. DeLeon-Pennell, K.Y.; Meschiari, C.A.; Jung, M.; Lindsey, M.L. Matrix metalloproteinases in myocardial infarction and heart failure. Prog. Mol. Biol. Transl. Sci. 2017, 147, 75-100. [PubMed]

153. Lovett, D.H.; Chu, C.; Wang, G.; Ratcliffe, M.B.; Baker, A.J. A N-terminal truncated intracellular isoform of matrix metalloproteinase-2 impairs contractility of mouse myocardium. Front. Physiol. 2014, 5, 363. [CrossRef] [PubMed]

154. Giri, B.; Dey, S.; Das, T.; Sarkar, M.; Banerjee, J.; Dash, S.K. Chronic hyperglycemia mediated physiological alteration and metabolic distortion leads to organ dysfunction, infection, cancer progression and other pathophysiological consequences: An update on glucose toxicity. Biomed. Pharmacother. 2018, 107, 306-328. [CrossRef] [PubMed]

155. Gliozzi, M.; Scarano, F.; Musolino, V.; Carresi, C.; Scarcella, A.; Nucera, S.; Scicchitano, M.; Ruga, S.; Bosco, F.; Maiuolo, J.; et al. Paradoxical effect of fat diet in matrix metalloproteinases induced mitochondrial dysfunction in diabetic cardiomyopathy. J. Cardiovasc. Med. (Hagerstown) 2020. [CrossRef]

156. Ilkan, Z.; Akar, F.G. The Mitochondrial Translocator Protein and the Emerging Link between Oxidative Stress and Arrhythmias in the Diabetic Heart. Front. Physiol. 2018, 9, 1518. [CrossRef]

157. Motloch, L.J.; Hu, J.; Akar, F.G. The mitochondrial translocator protein and arrhythmogenesis in ischemic heart disease. Oxid. Med. Cell. Longev. 2015, 2015, 234104. [CrossRef]

158. Searles, C.D. The nitric oxide pathway and oxidative stress in heart failure. Congest. Heart Fail. 2002, 8, $142-155$.

159. Carnicer, R.; Crabtree, M.J.; Sivakumaran, V.; Casadei, B.; Kass, D.A. Nitric oxide synthases in heart failure. Antioxid. Redox Signal. 2013, 18, 1078-1099. [CrossRef]

160. Ebong, I.A.; Goff, D.C.; Rodriguez, C.J.; Chen, H.; Bertoni, A.G. Mechanisms of heart failure in obesity. Obes. Res. Clin. Pract. 2014, 8, e540-e548. [CrossRef]

161. Roger, V.L.; Go, A.S.; Lloyd-Jones, D.M.; Adams, R.J.; Berry, J.D.; Brown, T.M.; Carnethon, M.R.; Dai, S.; de Simone, G.; Ford, E.S.; et al. Heart disease and stroke statistics-2011 update: A report from the American Heart Association. Circulation 2011, 123, e18-e209. [CrossRef]

162. Greene, S.J.; Gheorghiade, M.; Borlaug, B.A.; Pieske, B.; Vaduganathan, M.; Burnett, J.C.; Roessig, L.; Stasch, J.P.; Solomon, S.D.; Paulus, W.J.; et al. The cGMP signaling pathway as a therapeutic target in heart failure with preserved ejection fraction. J. Am. Heart Assoc. 2013, 2, e000536. [CrossRef] [PubMed]

163. Li, Q.; Yon, J.Y.; Cai, H. Mechanisms and consequences of eNOS dysfunction in hypertension. J. Hypertens. 2015, 33, 1128-1136. [CrossRef] [PubMed] 
164. Tsai, E.J.; Liu, Y.; Koitabashi, N.; Bedja, D.; Danner, T.; Jasmin, J.F.; Lisanti, M.; Friebe, A.; Takimoto, E.; Kass, D.A. Pressureoverload-induced subcellular relocalization/oxidation of soluble guanylyl cyclase in the heart modulates enzyme stimulation. Circ. Res. 2012, 110, 295-303. [CrossRef] [PubMed]

165. Kim, G.E.; Kass, D.A. Cardiac phosphodiesterases and their modulation for treating heart disease. Handb. Exp. Pharmacol. 2017, $243,249-269$.

166. Nagendran, J.; Archer, S.L.; Soliman, D.; Gurtu, V.; Moudgil, R.; Haromy, A.; St Aubin, C.; Webster, L.; Rebeyka, I.M.; Ross, D.B.; et al. Phosphodiesterase type 5 is highly expressed in the hypertrophied human right ventricle, and acute inhibition of phosphodiesterase type 5 improves contractility. Circulation 2007, 116, 238-248. [CrossRef]

167. Blanton, R.M. cGMP signaling and modulation in heart failure. J. Cardiovasc. Pharmacol. 2020, 75, 385-398. [CrossRef]

168. Methawasin, M.; Strom, J.; Borkowski, T.; Hourani, Z.; Runyan, R.; Smith, J.E., III; Granzier, H. Phosphodiesterase 9a inhibition in mouse models of diastolic dysfunction. Circ. Heart Fail. 2020, 13, e006609. [CrossRef]

169. Takimoto, E.; Koitabashi, N.; Hsu, S.; Ketner, E.A.; Zhang, M.; Nagayama, T.; Bedja, D.; Gabrielson, K.L.; Blanton, R.; Siderovski, D.P.; et al. Regulator of $G$ protein signaling 2 mediates cardiac compensation to pressure overload and antihypertrophic effects of PDE5 inhibition in mice. J. Clin. Investig. 2009, 119, 408-420. [CrossRef]

170. Lee, D.I.; Zhu, G.; Sasaki, T.; Cho, G.S.; Hamdani, N.; Holewinski, R.; Jo, S.H.; Danner, T.; Zhang, M.; Rainer, P.P. Phosphodiesterase 9A controls nitric-oxide-independent cGMP and hypertrophic heart disease. Nature 2015, 519, 472-476. [CrossRef]

171. Van Heerebeek, L.; Paulus, W.J. Understanding heart failure with preserved ejection fraction: Where are we today? Neth. Heart J. 2016, 24, 227-236. [CrossRef]

172. Verma, S.; McMurray, J.J.V. SGLT2 inhibitors and mechanisms of cardiovascular benefit: A state-of-the-art review. Diabetologia 2018, 61, 2108-2117. [CrossRef] [PubMed]

173. Gambardella, J.; Lombardi, A.; Santulli, G. Metabolic flexibility of mitochondria plays a key role in balancing glucose and fatty acid metabolism in the diabetic heart. Diabetes 2020, 69, 2054-2057. [CrossRef] [PubMed]

174. Leichman, J.G.; Aguilar, D.; King, T.M.; Vlada, T.A.; Reyes, E.; Taegtmeyer, H. Association of plasma free fatty acids and left ventricular diastolic function in patients with clinically severe obesity. Am. J. Clin. Nutr. 2006, 84, 336-341. [CrossRef] [PubMed]

175. Ekanayake, P.; Hupfeld, C.; Mudaliar, S. Sodium-glucose cotransporter Type 2 (SGLT-2) inhibitors and ketogenesis: The Good and the Bad. Curr. Diab. Rep. 2020, 20,1-10. [CrossRef]

176. Ferrannini, E.; Mark, M.; Mayoux, E. CV protection in the EMPA-REG OUTCOME Trial: A “Thrifty Substrate" hypothesis. Diabetes Care 2016, 39, 1108-1114. [CrossRef]

177. Mizuno, Y.; Harada, E.; Nakagawa, H.; Morikawa, Y.; Shono, M.; Kugimiya, F.; Yoshimura, M.; Yasue, H. The diabetic heart utilizes ketone bodies as an energy source. Metabolism 2007, 77, 65-72. [CrossRef]

178. Gormsen, L.C.; Svart, M.; Thomsen, H.H.; Søndergaard, E.; Vendelbo, M.H.; Christensen, N.; Tolbod, L.P.; Harms, H.J.; Nielsen, R.; Wiggers, H.; et al. Ketone body infusion with 3-hydroxybutyrate reduces myocardial glucose uptake and increases blood flow in humans: A positron emission tomography study. J. Am. Heart Assoc. 2017, 6, e005066. [CrossRef]

179. Santos-Gallego, C.G.; Ibanez, J.A.R.; San Antonio, R.; Ishikawa, K.; Watanabe, S.; Botija, M.B.P.; Sanz Salvo, A.J.; Hajjar, R.; Fuster, V.; Badimon, J. Empagliflozin induces a myocardial metabolic shift from glucose consumption to ketone metabolism that mitigates adverse cardiac remodeling and improves myocardial contractility. J. Am. Coll. Cardiol. 2018, 71, A674. [CrossRef]

180. Lopaschuk, G.D.; Verma, S. Empagliflozin's fuel hypothesis: Not so soon. Cell Metab. 2016, 24, 200-202. [CrossRef]

181. Kappel, B.A.; Lehrke, M.; Schutt, K.; Artati, A.; Adamski, J.; Lebherz, C.; Marz, N. Effect of empagliflozin on the metabolic signature of patients with type 2 diabetes mellitus and cardiovascular disease. Circulation 2017, 136, 969-972. [CrossRef]

182. Packer, M.; Anker, S.D.; Butler, J.; Filippatos, G.; Zannad, F. Effects of sodium-glucose cotransporter 2 inhibitors for the treatment of patients with heart failure: Proposal of a novel mechanism of action. JAMA Cardiol. 2017, 2, 1025-1029. [CrossRef] [PubMed]

183. Uthman, L.; Baartscheer, A.; Bleijlevens, B.; Schumacher, C.A.; Fiolet, J.W.T.; Koeman, A.; Jancev, M.; Hollmann, M.W.; Weber, N.C.; Coronel, R.; et al. Class effects of SGLT2 inhibitors in mouse cardiomyocytes and hearts: Inhibition of $\mathrm{Na}+/ \mathrm{H}+$ exchanger, lowering of cytosolic Na+ and vasodilation. Diabetologia 2018, 61, 722-726. [CrossRef] [PubMed]

184. Gallo, L.A.; Wright, E.M.; Vallon, V. Probing SGLT2 as a therapeutic target for diabetes: Basic physiology and consequences. Diab. Vasc. Dis. Res. 2015, 12, 78-89. [CrossRef] [PubMed]

185. Fedak, P.W.; Verma, S.; Weisel, R.D.; Li, R.K. Cardiac remodeling and failure from molecules to man (part II). Cardiovasc. Pathol. 2005, 14, 49-60. [CrossRef]

186. Lee, T.M.; Chang, N.C.; Lin, S.Z. Dapagliflozin, a selective SGLT2 inhibitor, attenuated cardiac fibrosis by regulating the macrophage polarization via STAT3 signaling in infarcted rat hearts. Free Radic. Biol. Med. 2017, 104, 298-310. [CrossRef]

187. Kang, S.; Verma, S.; Hassanabad, A.F.; Teng, G.; Belke, D.D.; Dundas, J.A.; Guzzardi, D.G.; Svystonyuk, D.A.; Pattar, S.S.; Park, D.S.J.; et al. Direct effects of empagliflozin on extracellular matrix remodeling in human cardiac fibroblasts: Novel translational clues to EMPA-REG Outcome. Can. J. Cardiol. 2020, 36, 543-553. [CrossRef]

188. Braunwald, E. The war against heart failure: The Lancet lecture. Lancet 2015, 385, 812-824. [CrossRef]

189. Gerber, Y.; Weston, S.A.; Enriquez-Sarano, M.; Berardi, C.; Chamberlain, A.M.; Manemann, S.M.; Jiang, R.; Dunlay, S.M.; Roger, V.L. Mortality associated with heart failure after myocardial infarction: A contemporary community perspective. Circ. Heart Fail. 2016, 9, e002460. [CrossRef] 
190. Gerber, Y.; Weston, S.A.; Berardi, C.; McNallan, S.M.; Jiang, R.; Redfield, M.M.; Roger, V.L. Contemporary trends in heart failure with reduced and preserved ejection fraction after myocardial infarction: A community study. Am. J. Epidemiol. 2013, 178, 1272-1280. [CrossRef]

191. Cruz, M.S.; da Silva, A.M.G.; da Souza, K.S.C.; Luchessi, A.D.; Silbiger, V.N. miRNAs emerge as circulating biomarkers of post-myocardial infarction heart failure. Heart Fail. Rev. 2020, 25, 321-329. [CrossRef]

192. Nadal-Ginard, B.; Torella, D.; De Angelis, A.; Rossi, F. Monographic issue of pharmacological research on adult myocardial repair/regeneration. Pharmacol. Res. 2018, 127, 1-3. [CrossRef] [PubMed]

193. Nadal-Ginard, B.; Ellison, G.M.; Torella, D. The cardiac stem cell compartment is indispensable for myocardial cell homeostasis, repair and regeneration in the adult. Stem. Cell. Res. 2014, 13 Pt B, 615-630. [CrossRef]

194. Beltrami, A.P.; Barlucchi, L.; Torella, D.; Baker, M.; Limana, F.; Chimenti, S.; Kasahara, H.; Rota, M.; Musso, E.; Urbanek, K.; et al. Adult cardiac stem cells are multipotent and support myocardial regeneration. Cell 2003, 114, 763-776. [CrossRef]

195. Chabot, B.; Stephenson, D.A.; Chapman, V.M.; Besmer, P.; Bernstein, A. The proto-oncogene c-kit encoding a transmembrane tyrosine kinase receptor maps to the mouse W locus. Nature 1988, 335, 88-89. [CrossRef] [PubMed]

196. Morrison, S.J.; Wandycz, A.M.; Hemmati, H.D.; Wright, D.E.; Weissman, I.L. Identification of a lineage of multipotent hematopoietic progenitors. Development 1997, 124, 1929-1939. [PubMed]

197. Sellers, S.E.; Tisdale, J.F.; Agricola, B.A.; Metzger, M.E.; Donahue, R.E.; Dunbar, C.E.; Sorrentino, B.P. The effect of multidrugresistance 1 gene versus neo transduction on ex vivo and in vivo expansion of rhesus macaque hematopoietic repopulating cells. Blood 2001, 97, 1888-1891. [CrossRef] [PubMed]

198. Nocka, K.; Majumder, S.; Chabot, B.; Ray, P.; Cervone, M.; Bernstein, A.; Besmer, P. Expression of c-kit gene products in known cellular targets of $\mathrm{W}$ mutations in normal and $\mathrm{W}$ mutant mice-evidence for an impaired c-kit kinase in mutant mice. Genes Dev. 1989, 3, 816-826. [CrossRef]

199. Vajravelu, B.N.; Hong, K.U.; Al-Maqtari, T.; Cao, P.; Keith, M.C.; Wysoczynski, M.; Zhao, J.; Moore, J.B., IV; Bolli, R. C-Kit promotes growth and migration of human cardiac progenitor cells via the PI3K-AKT and MEK-ERK Pathways. PLoS ONE 2015, 10, e0140798. [CrossRef]

200. Cimini, M.; Fazel, S.; Zhuo, S.; Xaymardan, M.; Fujii, H.; Weisel, R.D.; Li, R.K. c-kit dysfunction impairs myocardial healing after infarction. Circulation 2007, 116 (Suppl. 11), I77-I82. [CrossRef]

201. Li, M.; Naqvi, N.; Yahiro, E.; Liu, K.; Powell, P.C.; Bradley, W.E.; Martin, D.I.K.; Graham, R.M.; Dell'Italia, L.J.; Husain, A. c-kit is required for cardiomyocyte terminal differentiation. Circ. Res. 2008, 102, 677-685. [CrossRef]

202. Ye, L.; Zhang, E.Y.; Xiong, Q.; Astle, C.M.; Zhang, P.; Li, Q.; From, A.H.; Harrison, D.E.; Zhang, J.J. Aging Kit mutant mice develop cardiomyopathy. PLoS ONE 2012, 7, e33407. [CrossRef] [PubMed]

203. Lennartsson, J.; Rönnstrand, L. Stem cell factor receptor/c-Kit: From basic science to clinical implications. Physiol. Rev. 2012, 92, 1619-1649. [CrossRef] [PubMed]

204. Van Berlo, J.H.; Kanisicak, O.; Maillet, M.; Vagnozzi, R.J.; Karch, J.; Lin, S.C.; Middleton, R.C.; Marbán, E.; Molkentin, J.D. c-kit+ cells minimally contribute cardiomyocytes to the heart. Nature 2014, 509, 337-341. [CrossRef] [PubMed]

205. Vicinanza, C.; Aquila, I.; Cianflone, E.; Scalise, M.; Marino, F.; Mancuso, T.; Fumagalli, F.; Giovannone, E.D.; Cristiano, F.; Iaccino, E.; et al. Kit ${ }^{\text {cre }}$ knock-in mice fail to fate-map cardiac stem cells. Nature 2018, 555, E1-E5. [CrossRef] [PubMed]

206. Chimenti, C.; Kajstura, J.; Torella, D.; Urbanek, K.; Heleniak, H.; Colussi, C.; Di Meglio, F.; Nadal-Ginard, B.; Frustaci, A.; Leri, A.; et al. Senescence and death of primitive cells and myocytes lead to premature cardiac aging and heart failure. Circ. Res. 2003, 93, 604-613. [CrossRef] [PubMed]

207. Torella, D.; Rota, M.; Nurzynska, D.; Musso, E.; Monsen, A.; Shiraishi, I.; Zias, E.; Walsh, K.; Rosenzweig, A.; Sussman, M.A.; et al. Cardiac stem cell and myocyte aging, heart failure, and insulin-like growth factor-1 overexpression. Circ. Res. 2004, 94, 514-524. [CrossRef] [PubMed]

208. Chua, C.C.; Gao, J.; Ho, Y.S.; Xu, X.; Kuo, I.C.; Chua, K.Y.; Wang, H.; Hamdy, R.C.; Reed, J.C.; Chua, B.H. Over-expression of a modified bifunctional apoptosis regulator protects against cardiac injury and doxorubicin-induced cardiotoxicity in transgenic mice. Cardiovasc. Res. 2009, 81, 20-27. [CrossRef] [PubMed]

209. Zakharova, L.; Nural-Guvener, H.; Nimlos, J.; Popovic, S.; Gaballa, M.A. Chronic heart failure is associated with transforming growth factor beta-dependent yield and functional decline in atrial explant-derived c-Kit+ cells. J. Am. Heart Assoc. 2013, 2, e000317. [CrossRef]

210. Itzhaki-Alfia, A.; Leor, J.; Raanani, E.; Sternik, L.; Spiegelstein, D.; Netser, S.; Holbova, R.; Pevsner-Fischer, M.; Lavee, J.; Barbash, I.M. Patient characteristics and cell source determine the number of isolated human cardiac progenitor cells. Circulation 2009, 120, 2559-2566. [CrossRef]

211. Huang, C.; Zhang, X.; Ramil, J.M.; Rikka, S.; Kim, L.; Lee, Y.; Gude, N.A.; Thistlethwaite, P.A.; Sussman, M.A.; Gottlieb, R.A.; et al. Juvenile exposure to anthracyclines impairs cardiac progenitor cell function and vascularization resulting in greater susceptibility to stress-induced myocardial injury in adult mice. Circulation 2010, 121, 675-683. [CrossRef]

212. Carresi, C.; Musolino, V.; Gliozzi, M.; Maiuolo, J.; Mollace, R.; Nucera, S.; Maretta, A.; Sergi, D.; Muscoli, S.; Gratteri, S.; et al. Anti-oxidant effect of bergamot polyphenolic fraction counteracts doxorubicin-induced cardiomyopathy: Role of autophagy and ckitposCD45negCD31neg cardiac stem cell activation. J. Mol. Cell. Cardiol. 2018, 119, 10-18. [CrossRef] [PubMed]

213. Enriqueza, J.A.; Lenazb, G. Coenzyme Q and the Respiratory Chain: Coenzyme Q Pool and Mitochondrial Supercomplexes. Mol. Syndromol. 2014, 5, 119-140. [CrossRef] [PubMed] 
214. Ayer, A.M.P.; Stocker, R. CoQ10 function and role in heart failure and ischemic heart disease. Annu. Rev. Nutr. 2015, $2015,175-213$. [CrossRef] [PubMed]

215. Crane, F.L. Discovery of ubiquinone (coenzyme Q) and an overview of function. Mitochondrion 2007, 7, S2-S7. [CrossRef]

216. Burridge, P.W.; Li, Y.F.; Matsa, E.; Wu, H.; Ong, S.G.; Sharma, A.; Holmström, A.; Chang, A.C.; Coronado, M.J.; Ebert, A.D.; et al. Human induced pluripotent stem cell-derived cardiomyocytes recapitulate the predilection of breast cancer patients to doxorubicin-induced cardiotoxicity. Nat. Med. 2016, 22, 547-556. [CrossRef]

217. Milano, G.; Biemmi, V.; Lazzarini, E.; Balbi, C.; Ciullo, A.; Bolis, S.; Ameri, P.; Di Silvestre, D.; Mauri, P.; Barile, L.; et al. Intravenous administration of cardiac progenitor cell-derived exosomes protects against doxorubicin/trastuzumab-induced cardiac toxicity. Cardiovasc. Res. 2020, 116, 383-392. [CrossRef]

218. Barbaro, B.; Toietta, G.; Maggio, R.; Arciello, M.; Tarocchi, M.; Galli, A.; Balsano, C. Effects of the Olive-Derived Polyphenol Oleuropein on Human Health. Int. J. Mol. Sci. 2014, 15, 18508-18524. [CrossRef]

219. Vogel, P.; Machado, I.K.; Garavaglia, J.; Zani, V.T.; de Souza, D.; Dal Bosco, S.M. Polyphenols benefits of olive leaf (Olea europaea L.) to human health. Nutr. Hosp. 2015, 31, 1427-1433.

220. Rizzo, M.; Ventrice, D.; Giannetto, F.; Cirinnà, S.; Santagati, N.A.; Procopio, A.; Mollace, V.; Muscoli, C. Antioxidant activity of oleuropein and semisynthetic acetyl-derivatives determined by measuring malondialdehyde in rat brain. J. Pharm. Pharmacol. 2017, 69, 1502-1512. [CrossRef]

221. Romani, A.; Ieri, F.; Urciuoli, S.; Noce, A.; Marrone, G.; Nediani, C.; Bernini, R. Effects of phenolic compounds found in extra-virgin olive oil, by-products, and leaf of Olea europaea L. Nutrients 2019, 11, 1776. [CrossRef]

222. Taamalli, A.; Feriani, A.; Lozano-Sanchez, J.; Ghazouani, L.; El Mufti, A.; Allagui, M.S.; Segura-Carretero, A.; Mhamdi, R.; Arráez-Roman, D. Potential hepatoprotective activity of super critical carbon dioxide olive leaf extracts against CCl4-Induced Liver Damage. Foods 2020, 9, 804. [CrossRef] [PubMed]

223. Okrouhlá, M.; Stupka, R.; Čítek, J.; Lebedová, N.; Zadinová, K. Effect of duration of dietary rapeseed and soybean oil feeding on physical characteristics, fatty acid profile, and oxidative stability of pig backfat. Animals 2018, 8, 193. [CrossRef] [PubMed]

224. Flori, L.; Donnini, S.; Calderone, V.; Zinnai, A.; Taglieri, I.; Venturi, F.; Testai, L. The nutraceutical value of olive oil and its bioactive constituents on the cardiovascular system. Focusing on main strategies to slow down its quality decay during production and storage. Nutrients 2019, 11, 1962.

225. Beltran, G.; Aguilera, M.P.; Del-Rio, C.; Sanchez, S.; Martinez, L. Influence of fruit ripening on the natural antioxidant content of Hojiblanca virgin olive oils. Food Chem. 2005, 89, 207-215. [CrossRef]

226. Bulotta, S.; Celano, M.; Lepore, S.M.; Montalcini, T.; Pujia, A.; Russo, D. Beneficial effects of the olive oil phenolic components oleuropein and hydroxytyrosol: Focus on protection against cardiovascular and metabolic diseases. J. Transl. Med. 2014, 12, 219. [CrossRef]

227. Bendini, A.; Cerretani, L.; Carrasco-Pancorbo, A.; Gómez-Caravaca, A.M.; Segura-Carretero, A.; Fernández-Gutiérrez, A.; Lercker, G. Phenolic molecules in virgin olive oils: A survey of their sensory properties, health effects, antioxidant activity and analytical methods. An overview of the last decade. Molecules 2007, 12, 1679-1719. [CrossRef]

228. Servili, M.; Montedoro, G. Contribution of phenolic compound to virgin olive oil quality. Eur. J. Lipid Sci. Technol. 2002, 104, 602-613. [CrossRef]

229. Tripoli, E.; Giammanco, M.; Tabacchi, G.; Di Majo, D.; Giammanco, S.; La Guardia, M. The phenolic compounds of olive oil: Structure, biological activity and beneficial effects on human health. Nutr. Res. Rev. 2005, 18, 98-112. [CrossRef]

230. Nediani, C.; Ruzzolini, J.; Romani, A.; Calorini, L. Oleuropein, a bioactive compound from Olea europaea L., as a potential preventive and therapeutic agent in non-communicable diseases. Antioxidants 2019, 8, 578. [CrossRef]

231. Zhang, X.Z.; Zhao, Y.B.; Li, C.M.; Chen, D.M.; Wang, G.P.; Chang, R.F.; Shu, H. Potential polyphenol markers of phase change in apple (Malus domestica). J. Plant. Physiol. 2007, 164, 574-580. [CrossRef]

232. Rodríguez-Pérez, C.; García-Villanova, B.; Guerra-Hernández, E.; Verardo, V. Grape Seeds proanthocyanidins: An overview of in vivo bioactivity in animal models. Nutrients 2019, 11, 2435. [CrossRef] [PubMed] 